\title{
Multifunctional floodplain management and biodiversity effects: a knowledge synthesis for six European countries
}

\author{
Stefan Schindler ${ }^{1,2}$ (D) Fionnuala H. O'Neill ${ }^{3}$ • \\ Marianna Biró $^{4}$ - Christian Damm ${ }^{5} \cdot$ Viktor Gasso $^{6}$. \\ Robert Kanka $^{7}$ - Theo van der Sluis ${ }^{8}$ - Andreas Krug 9 \\ Sophie G. Lauwaars ${ }^{10}$ - Zita Sebesvari ${ }^{11}$ - Martin Pusch ${ }^{12}$. \\ Boris Baranovsky ${ }^{6}$ - Thomas Ehlert' - Bernd Neukirchen' \\ James R. Martin ${ }^{3}$ - Katrin Euller ${ }^{1,13}$ • Volker Mauerhofer ${ }^{14}$. \\ Thomas Wrbka ${ }^{1}$
}

Received: 24 December 2015/Revised: 27 April 2016/Accepted: 7 May 2016/

Published online: 30 May 2016

(C) The Author(s) 2016. This article is published with open access at Springerlink.com

\begin{abstract}
Floodplain ecosystems are biodiversity hotspots and supply multiple ecosystem services. At the same time they are often prone to human pressures that increasingly impact their intactness. Multifunctional floodplain management can be defined as a management approach aimed at a balanced supply of multiple ecosystem services that serve the needs of
\end{abstract}

Communicated by Barbara Livoreil.

This is part of the special issue on Networking Biodiversity Knowledge.

Electronic supplementary material The online version of this article (doi:10.1007/s10531-016-1129-3) contains supplementary material, which is available to authorized users.

Stefan Schindler

stefan.schindler@umweltbundesamt.at

1 Department of Botany and Biodiversity Research, Division of Conservation Biology, Vegetation Ecology and Landscape Ecology, University of Vienna, Rennweg 14, 1030 Vienna, Austria

2 Department of Biodiversity and Nature Conservation, Environment Agency Austria, Spittelauer Lände 5, 1090 Vienna, Austria

3 Botanical Environmental \& Conservation Consultants Ltd., Dublin, Ireland

4 Institute of Ecology and Botany, Centre for Ecological Research, Hungarian Academy of Sciences, Vácrátót, Hungary

5 Karlsruhe Institute of Technology (KIT), Karlsruhe, Germany

6 Oles Honchar Dnipropetrovsk National University, Dnipropetrovsk, Ukraine

7 Institute of Landscape Ecology SAS, Bratislava, Slovakia

8 Alterra, Wageningen, The Netherlands

9 Federal Agency for Nature Conservation (BfN), Bonn, Germany

10 Rijkswaterstaat Centre for Infrastructure, Utrecht, The Netherlands 
the local residents, but also those of off-site populations that are directly or indirectly impacted by floodplain management and policies. Multifunctional floodplain management has been recently proposed as a key concept to reconcile biodiversity and ecosystem services with the various human pressures and their driving forces. In this paper we present biophysics and management history of floodplains and review recent multifunctional management approaches and evidence for their biodiversity effects for the six European countries Ireland, the Netherlands, Germany, Slovakia, Hungary and the Ukraine. Multifunctional use of floodplains is an increasingly important strategy in some countries, for instance in the Netherlands and Hungary, and management of floodplains goes hand in hand with sustainable economic activities resulting in flood safety and biodiversity conservation. As a result, biodiversity is increasing in some of the areas where multifunctional floodplain management approaches are implemented. We conclude that for efficient use of management resources and ecosystem services, consensual solutions need to be realized and biodiversity needs to be mainstreamed into management activities to maximize ecosystem service provision and potential human benefits. Multifunctionality is more successful where a broad range of stakeholders with diverse expertise and interests are involved in all stages of planning and implementation.

Keywords Ecosystem services · Flood protection - Green infrastructure $\cdot$ River Regulation - River restoration - Water framework directive

\section{Introduction}

Under natural conditions, biodiversity hotspots are often found near rivers, their banks and floodplains, as these areas represent habitats with high levels of structural and functional dynamics, primarily induced by downstream flow (Ward et al. 1999). Floodplains are often characterized by a mosaic of habitats differing in age, humidity, sediment properties, productivity, and diversity, abundance, composition and succession state of biota (Geilen et al. 2004). This habitat mosaic is inhabited by a multiplicity of generalist and specialist species, both terrestrial and aquatic, which often depend on the relative habitat quality and on proximity and functional connectivity of various habitat patches (Romanowski et al. 2005; Scholz et al. 2012). Historically rivers and their floodplains have served for multiple human uses including as major axes of migration, settlement, agriculture, forestry, fishery, industrial development and trade. This is not surprising, since monofunctional management of areas with such high potential for providing goods and services would be potentially inefficient (Secchi et al. 2012). Most floodplain areas have meanwhile been hydrologically disconnected from the river by the construction of dykes, and are currently often dominated by intense human use, such as agriculture, settlements or traffic routes (Hein et al. 2016) and Europe is the continent that is most affected by such activities (Nilsson et al. 2005).

\footnotetext{
11 Institute for Environment and Human Security, United Nations University, Bonn, Germany

12 Leibniz Institute of Freshwater Ecology and Inland Fisheries (IGB), Berlin, Germany

13 Gloria Project, Institute for Interdisciplinary Mountain Research, University of Natural Resources and Life Sciences Vienna, Austrian Academy of Sciences, Vienna, Austria 
Habitat conditions in the remaining active floodplain areas have often substantially been altered by human impacts, such as river training, river damming, floodplain disconnection, aggradation, pollution by fertilizers and chemical contaminants, introduction of invasive species, or by intense forestry (e.g. Nijland and Cals 2001; Leyer 2005; Rinaldi et al. 2013). Thus, most floodplains in Europe are degraded, especially due to reduced hydromorphological dynamics. This has led, among other things, to a decrease of dynamic habitat types which are an essential part of floodplains (Klimo et al. 2008). The resulting reduced rate of habitat turnover is accompanied by a decrease in the richness particularly of specialist and sensitive species that depend on the availability of newly formed habitat and sediment accumulations created by the natural patterns of high and low discharge levels (Poff et al. 1997).

Historical interventions in the functions and structures of European rivers and floodplains also enhanced the risk of devastating flood events (e.g. Somlyódi 2011). In the last decades, major floods occurred in Central Europe (1997, 1998, 1999, 2000, 2002, 2006, 2013), in the UK $(2002,2004,2005,2007,2009,2010,2012)$, and in Ireland (2009, 2012, 2015). A political answer of the EU to the first events was the launch of a Flood Directive (EC 2007). Furthermore, these major floods have triggered additional interest in floodplain areas, partly aimed at the increase and optimization of flood retention capacities. In cases of non-technical measures like dyke relocations, the establishment of flood retention areas has been shown, for instance, to provide a cost-effective protection against flood damage with significant ecological co-benefits (Grossmann et al. 2010).

This interest from governmental flood management administrations has opened new options and innovative co-financing opportunities to re-establish hydrological dynamics in floodplain areas that have previously been partially or fully disconnected. Within such floodplain management projects, any physical alterations and new management regimes should be agreed on by all stakeholders of the respective areas, in order to minimize potential conflicts of development aims. Thus, there is a need to establish and implement multifunctional approaches in floodplain management instead of sectoral narrow-focused actions, which may present great opportunities to restore degraded floodplain areas (Secchi et al. 2012; Schindler et al. 2014). However, in many places major target conflicts have not been resolved, land use pressures being a predominant issue in this context. Today no systematic approach exists to reconcile the various competing management goals.

Green Infrastructure has been increasingly proposed as a multifunctional solution for halting loss and fragmentation of habitats, and thus biodiversity, and for maintaining and restoring ecosystems and their services (EC 2011; EEA 2015). Green Infrastructure was defined in this context as "an interconnected network of green space that conserves natural ecosystem values and functions and provides associated benefits to human populations" (Benedict and McMahon 2002). Multifunctionality is a key feature of Green Infrastructure and commonly related to the functions of ecosystems and to the ecosystem services provided to human populations (MA 2005; Weber et al. 2006). Multifunctional floodplain management (MFM) can be defined as a management approach aimed at a balanced supply of ecosystem services, serving the needs of local and remote residents, who are directly or indirectly impacted by floodplain policies (cf. Secchi et al. 2012). Existing trade-offs imply in this context cut-backs in some provisioning services currently dominating many floodplain landscapes (Schindler et al. 2014).

In this study we applied the Driver-Pressure-State-Impact-Response (DPSIR) framework (EEA 2007) for selected temperate European floodplains. The aim of this study was to review status of biodiversity in floodplains, pressures and their impacts as well as multifunctional floodplain management as response and evidence for its effects on 
biodiversity. This study was conducted in the frame of the trial assessments for testing functionality and performance of the science-policy interface 'BiodiversityKnowledge' (Nesshöver et al. 2016; Schindler et al. 2016). Conducting this assessment also delivered some methodological insights for 'BiodiversityKnowledge' that will be highlighted in the discussion section (see also Schindler et al. 2016).

\section{Methods}

The research question 'Impact of multifunctional floodplain management on biodiversity and ecosystem services' was tackled by several methodological approaches in the frame of the trial assessment 'conservation case' for testing functionality and performance of the science-policy interface BiodiversityKnowledge, (Schindler et al. 2013a, b, 2014, 2016). The focus of the trial assessment was on temperate Europe, because floodplains under other climatic regimes, such as boreal or Mediterranean, have basic differences in their floodplain ecology and dynamics. The trial assessment strongly relied on a group of experts that was compiled by contacting knowledge hubs and individual knowledge holders (Schindler et al. 2013b) and covered multidisciplinary expertise on floodplains and had a broad geographic coverage (Schindler et al. 2014 supplementary material; 2016).

This assessment dealt with the six countries Ireland, the Netherlands, Germany, Slovakia, Hungary and the Ukraine covering temperate European floodplains along a WestEast gradient of approximately $4000 \mathrm{~km}$ (Fig. 1). The situation in each country was reviewed by one or more floodplain experts using their personal expertise in their resident country complemented by a review of the national literature. MFM projects were selected according to their relevance for the study aims as judged by the national experts. To reach consistency among contributions for each country, we understand floodplains for this study as 'low-relief earth surfaces composed of fluvial deposits that are frequently flooded (active floodplains) or formerly flooded (morphological floodplains) and are an integral part of catchments'(Tockner et al. 2010). Although the balanced provision of many functions and services should ideally be aimed for in MFM (Schindler et al. 2014; Plieninger et al. 2015), we further agreed to potentially consider bifunctional management

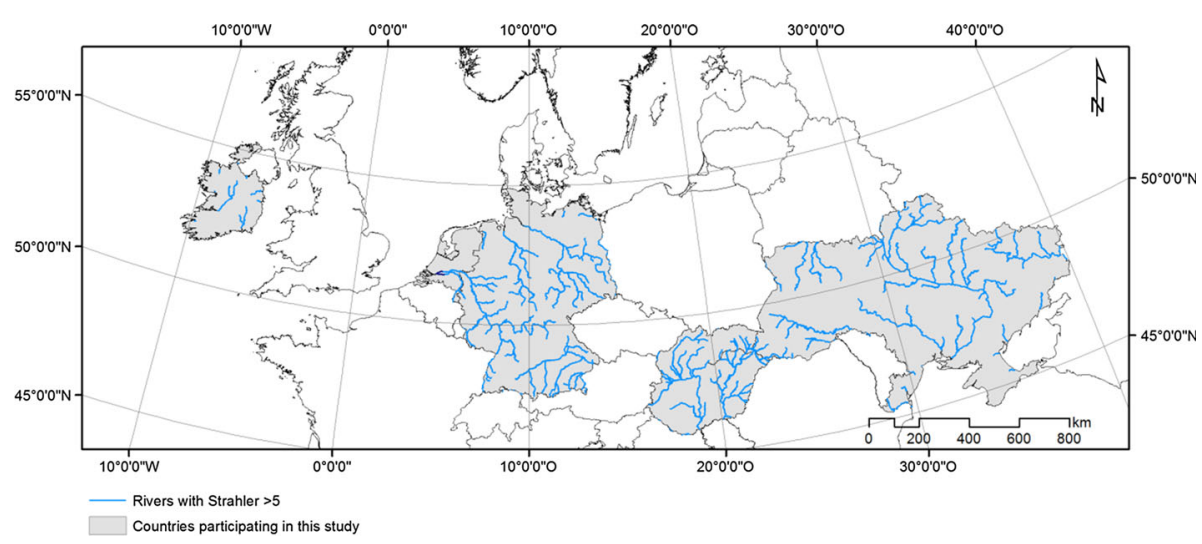

Fig. 1 The six countries (Ireland, the Netherlands, Germany, Slovakia, Hungary and the Ukraine) covered by this review and their main rivers 
strategies and projects, a minimalistic version of multifunctionality aiming at conservation or restoration of two functions only. We further agreed on applying the DPSIR-framework (EEA 2007; see Hein et al. 2016 for another DPSIR-application comparing different floodplains) to review status of biodiversity in floodplains, pressures on floodplain biodiversity and their impacts as well as MFM as response and evidence for its effects on biodiversity. We also predefined that the contributions should be narratives containing the information that was judged to me the most relevant for each section and that grey literature should be adequately considered, not least because other methods such as systematic reviews strongly relied on evidence published in international scientific journals, while it was challenges to integrate practical experience and local knowledge (Schindler et al. 2016). These narratives were complemented with tables that summarize a standardized way key information on floodplain habitats, pressures on floodplain biodiversity, impacts of floodplain management measures, and main elements of floodplain management approaches. Based on these country-specific assessments, we discuss interdisciplinary concepts that have been developed to create "win-win" situations in timely floodplain management, including substantial improvement of the ecological status of the respective floodplains. We further compared the relevance of the assessment in comparison to other products of the trial assessments of 'BiodiversityKnowledge'. In the following we present the result of our assessment in the order (i) status, (ii) pressures and impacts, and (iii) response.

\section{Results}

\section{Status: rivers, floodplains and their biodiversity in the six countries}

In Ireland, there are 74,000 $\mathrm{km}$ of river channel including 38,000 $\mathrm{km}$ of the smallest order streams (Byrne and Fanning 2015). Larger Irish rivers, such as the Shannon, Lee, Suir, Nore, Barrow, Slaney, Munster Blackwater and Boyne, often have extensive floodplains. The River Shannon catchment alone covers an area of $14,700 \mathrm{~km}^{2}$, and one-fifth of the land area of Ireland ultimately drains into the Shannon system (Browne et al. 2002). For administrative reasons Ireland has been divided into seven river basin districts due to the requirements of the Water Framework Directive (WFD) (DECLG 2013). Many of Ireland's rivers, including the eight listed above, are designated under the EU Habitats Directive as Special Areas of Conservation (SACs) for the conservation of fish, lamprey, otter and several other aquatic species listed in Annex II of the EU Habitats Directive (Dromey and O'Keeffe 2004). Irish floodplains are also important areas for bird species listed in Annex I of the EU Birds Directives such as Greenland White-fronted Goose (Anser albifrons flavirostris), Whooper Swan (Cygnus cygnus) and kingfisher (Alcedo atthis). Irish floodplain habitats of conservation concern include Molinia meadows and Alluvial forests (Table 1).

The Netherlands are dominated by the Rhine river delta, consisting of the main branches Ijssel, Lower Rhine and Waal. Rivers with smaller catchments are the Eems and Scheldt. Being at the bottom end of these rivers has a particular impact on the Dutch landscape morphology, but also on river dynamics. In the Netherlands rivers and consecutive wetlands form the backbone for the National Ecological Network and create with their floodplains a corridor through different lowland landscapes (Van der Sluis et al. 2004). Nationwide the network NATURA2000 networks covers $10.8 \%$ of the terrestrial area, 
Table 1 Habitat types listed in Annex I of the FFH directive that typically occur in the floodplains of the six countries under investigation

\begin{tabular}{|c|c|c|c|c|c|c|c|}
\hline Code & Name of the habitat type & IE & NL & $\mathrm{DE}$ & SK & $\mathrm{HU}$ & UA \\
\hline 2330 & Inland dunes with open Corynephorus and Agrostis grasslands & & & $\mathrm{x}$ & & & $\mathrm{x}$ \\
\hline 3130 & $\begin{array}{l}\text { Oligotrophic to mesotrophic standing waters with vegetation of } \\
\text { the Littorelletea uniflorae and/or Isoeto-Nanojuncetea }\end{array}$ & & $\mathrm{x}$ & $\mathrm{x}$ & $\mathrm{x}$ & $\mathrm{x}$ & $\mathrm{x}$ \\
\hline 3140 & $\begin{array}{l}\text { Hard oligo-mesotrophic waters with benthic vegetation of } \\
\text { Chara spp. }\end{array}$ & & $\mathrm{x}$ & & $\mathrm{x}$ & & $\mathrm{x}$ \\
\hline 3150 & $\begin{array}{l}\text { Natural eutrophic lakes with Magnopotamion or } \\
\text { Hydrocharition-type vegetation }\end{array}$ & & $\mathrm{x}$ & $\mathrm{x}$ & $\mathrm{x}$ & $\mathrm{x}$ & $\mathrm{x}$ \\
\hline 3220 & Alpine rivers and the herbaceous vegetation along their banks & & & $\mathrm{x}$ & $\mathrm{x}$ & & $\mathrm{x}$ \\
\hline 3230 & $\begin{array}{l}\text { Alpine rivers and their ligneous vegetation with Myricaria } \\
\text { germanica }\end{array}$ & & & $\mathrm{x}$ & $\mathrm{x}$ & & $\mathrm{x}$ \\
\hline 3240 & $\begin{array}{l}\text { Alpine rivers and their ligneous vegetation with Salix } \\
\text { elaeagnos }\end{array}$ & & & $\mathrm{x}$ & $\mathrm{x}$ & & $\mathrm{x}$ \\
\hline 3260 & $\begin{array}{l}\text { Water courses of plain to montane levels with the Ranunculion } \\
\text { fluitantis and Callitricho-Batrachion vegetation }\end{array}$ & $\mathrm{x}$ & $\mathrm{x}$ & $\mathrm{x}$ & $\mathrm{x}$ & $\mathrm{x}$ & $\mathrm{x}$ \\
\hline 3270 & $\begin{array}{l}\text { Rivers with muddy banks with Chenopodion rubri p.p. and } \\
\text { Bidention p.p. vegetation }\end{array}$ & $\mathrm{x}$ & $\mathrm{x}$ & $\mathrm{x}$ & $\mathrm{x}$ & $\mathrm{x}$ & $\mathrm{x}$ \\
\hline 6120 & Xeric sand calcareous grassland (Koelerion glaucae) & & $\mathrm{x}$ & $\mathrm{x}$ & & & $\mathrm{x}$ \\
\hline 6130 & Calaminarian grasslands of the Violetalia calamina & & $\mathrm{x}$ & & & & \\
\hline $6210^{*}$ & $\begin{array}{l}\text { Semi-natural dry grasslands and scrubland facies on calcareous } \\
\text { substrates (Festuco-Brometalia) (* important orchid sites) }\end{array}$ & & $\mathrm{x}$ & & & & $\mathrm{x}$ \\
\hline 6410 & $\begin{array}{l}\text { Molinia meadows on calcareous, peaty or clayey-silt-laden } \\
\text { soils (Molinion caeruleae) }\end{array}$ & $\mathrm{x}$ & $\mathrm{x}$ & $\mathrm{x}$ & $\mathrm{x}$ & & $\mathrm{x}$ \\
\hline 6430 & $\begin{array}{l}\text { Hydrophilous tall herb fringe communities of plains and of the } \\
\text { montane to alpine levels }\end{array}$ & $\mathrm{x}$ & $\mathrm{x}$ & $\mathrm{x}$ & $\mathrm{x}$ & $\mathrm{x}$ & $\mathrm{x}$ \\
\hline 6440 & Alluvial meadows of river valleys of the Cnidion dubii & & & $x$ & $\mathrm{x}$ & $\mathrm{x}$ & $\mathrm{x}$ \\
\hline 6510 & $\begin{array}{l}\text { Lowland hay meadows (Alopecurus pratensis, Sanguisorba } \\
\text { officinalis) }\end{array}$ & $\mathrm{x}$ & $\mathrm{x}$ & $\mathrm{x}$ & $\mathrm{x}$ & & $\mathrm{x}$ \\
\hline 7230 & Alkaline fens & $\mathrm{x}$ & $\mathrm{x}$ & & & & $\mathrm{x}$ \\
\hline 9160 & $\begin{array}{l}\text { Sub-Atlantic and medio-European oak or oak-hornbeam forests } \\
\text { of the Carpinion betuli }\end{array}$ & & & $\mathrm{x}$ & & & $x$ \\
\hline 91D0* & Bog woodland & & $\mathrm{x}$ & & & & $x$ \\
\hline $91 \mathrm{E} 0 *$ & $\begin{array}{l}\text { Mixed ash-alder alluvial forests with Alnus glutinosa and } \\
\text { Fraxinus excelsior (Alno-Padion, Alnion incanae, Salicion } \\
\text { albae) }\end{array}$ & $\mathrm{x}$ & $\mathrm{x}$ & $\mathrm{x}$ & $\mathrm{x}$ & $\mathrm{x}$ & $\mathrm{x}$ \\
\hline $91 \mathrm{~F} 0$ & $\begin{array}{l}\text { Riparian mixed forests of Quercus robur, Ulmus laevis and } \\
\text { Ulmus minor, Fraxinus excelsior or Fraxinus angustifolia, } \\
\text { along the great rivers (Ulmenion minoris) }\end{array}$ & & $\mathrm{x}$ & $\mathrm{x}$ & $\mathrm{x}$ & $\mathrm{x}$ & $\mathrm{x}$ \\
\hline
\end{tabular}

$I E$ Ireland, $N L$ the Netherlands, $D E$ Germany, $S K$ Slovakia, $H U$ Hungary, UA Ukraine

*Indicates a priority habitat type

whereas almost $60 \%$ of the active floodplains are NATURA2000 including fifteen Annex I habitat types (Table 1).

In Germany there is a wide range of different river and floodplain types, from alpine streams to lowland rivers (Dister et al. 1990; Koenzen 2005; Pottgießer and Sommerhäuser 2008), supporting multiple types of uses of both aquatic and riparian areas. The large catchments of the Rhine, Elbe, Danube, Weser, Ems and Odra dominate the hydrographic 
system, overlain by the topographical regions of the alpine/prealpine, the central low mountain range and the northern lowlands. Some rivers and floodplains in Germany are still hotspots of biodiversity (Ackermann and Sachteleben 2012) but a nationwide inventory of floodplains in quantity and quality has revealed great losses on both scales, their value slowly and steadily decreasing in nearly all parts of the country (2009; BMU 2009). Nationwide the network of 5,253 NATURA2000 sites covers $14.5 \%$ of the terrestrial area, whereas more than $50 \%$ of the active floodplains are NATURA2000 sites with a considerable number of Annex I habitat types (e.g. large areas of alluvial forests and lowland hay meadows, see Table 1) and Annex II species.

Slovakia has a dense network of streams; its territory is crossed by the main European watershed between the Black Sea (96\% of the Slovak catchment area) and the Baltic Sea (4\% in northern Slovakia). There are 32 rivers in Slovakia, the Váh (406 km), the Hron $(298 \mathrm{~km})$ and the Nitra $(193 \mathrm{~km})$ are the longest. Nationwide the NATURA2000 network covers $29.6 \%$ of the terrestrial area, whereas $58 \%$ of the active floodplains are located in fifteen NATURA2000 sites (Stanová and Valachovič 2002). Annex I habitat types in floodplains mainly include Ranunculion fluitantis and Callitricho-Batrachion vegetation, hydrophilous tall herb fringe communities, alluvial forests and riparian mixes forests (Table 1). However, forest habitats have been strongly impacted by anthropogenic pressures during the last 70 years and occur in many places only as small fragments of primary tree species composition or as larger complexes with changed species composition in behalf of planted clone poplars (Dister 1999; Oszlányi 1999). Biodiversity related to rivers is rich and varied, many taxa are listed in Annex II Habitats Directive; e.g. the animals Lutra lutra, Castor fiber, Ciconia nigra, Charadrius dubius, Haliaeetus albicilla, Gobio kessleri, Zingel streber and Lycaena dispar that are partly important indicator species for floodplains (Dister 1999).

Hungary's most important river is the Danube (in Hungary 417 km) (Somogyi 2001). Its largest tributary, the Tisza, collects water from the Carpathians. Reaching the lowland areas of Hungary, both rivers slow down, get middle section character and form one of the largest floodplains of Europe (Somogyi 2001). They are characterized by alluvial meadows and tall herb communities, open water surfaces, marshes, fens and reed beds and the characteristic standing water communities in the backwaters (Table 1) (Molnár et al. 2008a; Haraszthy 2014). The Hungarian rivers are currently bordered by willow shrubs, alluvial forests and riparian mixed forests (Table 1) (Haraszthy 2014).

The Ukraine has nine rivers with catchment basins larger than $50,000 \mathrm{~km}^{2}$. There are 43 lakes with a surface of more than $10 \mathrm{~km}^{2}$ and most of them are situated in floodplains (Gusieva 2012). The basins of Dnieper, Southern Bug and Severski Donets lie mostly within Ukraine, whereas the largest parts of the other catchments are located in neighbouring countries (Romanenko 2004). Despite recent losses due to human impact, floodplains are still rich in biodiversity and host almost all Annex I habitat types typical for floodplains in any of the other five countries (Table 1). Also $80 \%$ of the Ukrainian tetrapode species including 27 species of herpetofauna (Bulakhov et al. 2007; Gasso 2009; Giller 2002) and 300 bird species (Bulakhov et al. 2008). They also host more than 700 species of algae (Gerasimova 2006), 1000 species of vascular plants (Koreliakova 1977; Baranovsky 2000; Baranovsky and Aleksandrova 2005), 250 species of zooplankton (Mykolaichuk 2006), 200 species of zoobenthos (Zagubizhenko 1999), and 65 fish species (Kochet 2010). 


\section{Pressures and impact: relevant pressures on rivers and floodplains, historical floodplain regulation and its biodiversity effects}

In Ireland, land use developments that affect rivers and their floodplains include agricultural intensification, urbanization and housing developments, tourism and leisure activities, peat extraction and forestry. However, as in several other countries the most important pressures for floodplain biodiversity are alterations of hydrological conditions and invasive alien species (Table 2). Agricultural intensification over the last 50 years has resulted in the drainage of wetlands, channelization of rivers, and has contributed to the increased eutrophication of Ireland's rivers, which is an important threat for aquatic biodiversity (Moorkens 2000). In recent decades, and especially over the last 20 years, urbanization and building on floodplains in particular has become a problem, with the destruction of wetland areas resulting in flooding problems for residents in these areas. Forestry and its clearfelling may also cause problems, as clear-felled areas suffer from a range of impacts including soil erosion, with the resulting soil particles washing into river systems (Giller et al. 2002; Hutton et al. 2008). Similarly, the drainage of bogs, often a precursor to peat extraction, can result in increased siltation into rivers (Moorkens 2000), as can the extraction process itself (Anonymous 2003).

There is a long history of regulating rivers for power generation and transportation services (O'Grady 2006). The channelization of rivers and the associated dredging and building of earth embankments greatly reduced the size of floodplains. Rivers have also been regulated to improve the supply of water to major cities; one of the largest such projects, the Poulaphouca Reservoir on the River Liffey, was commissioned in 1938 to serve hydro power generation and the water supply needs of Dublin city (ESB 2015). The rivers Shannon and Lee have also been regulated for hydro power, with the Ardnacrusha hydro power plant the first to be commissioned, in 1929 (ESB 2015). Severe water shortages were experienced in Dublin between 2010 and 2013 and it is planned to obtain water from the Shannon river system for the Irish capital (Irish Water 2015a, b).

Table 2 Pressures on floodplain biodiversity in the six investigated countries as estimated by the authors of this study and ranked according to overall relevance

\begin{tabular}{|c|c|c|c|c|c|c|c|c|}
\hline Pressure & IE & NL & GE & SK & $\mathrm{HU}$ & UA & Mean & $\mathrm{SD}$ \\
\hline Alteration of hydraulic conditions & 5 & 5 & 5 & 5 & 5 & 5 & 5.0 & 0.0 \\
\hline Alien species & 4 & 1 & 3 & 5 & 5 & 5 & 3.8 & 1.5 \\
\hline Agriculture & 3 & 4 & 3 & 3 & 3 & 3 & 3.2 & 0.4 \\
\hline Forestry & 2 & 1 & 3 & 4 & 4 & 3 & 2.8 & 1.1 \\
\hline Water pollution and eutrophication & 3 & 3 & 1 & 4 & 2 & 4 & 2.8 & 1.1 \\
\hline Settlements and industrial infrastructure & 3 & 2 & 3 & 3 & 2 & 4 & 2.8 & 0.7 \\
\hline Soil pollution & 3 & 4 & 2 & 3 & 2 & 3 & 2.8 & 0.7 \\
\hline Hydropower & 2 & 0 & 3 & 4 & 3 & 4 & 2.7 & 1.4 \\
\hline Mining and quarrying & 3 & 2 & 3 & 2 & 1 & 4 & 2.5 & 1.0 \\
\hline Recreation & 2 & 2 & 1 & 3 & 1 & 3 & 2.0 & 0.8 \\
\hline Navigation (incl. navigation infrastructure) & 0 & 3 & 3 & 2 & 1 & 1 & 1.7 & 1.1 \\
\hline Transport infrastructure (excluding navigation) & 1 & 1 & 2 & 2 & 1 & 2 & 1.5 & 0.5 \\
\hline
\end{tabular}

$I E$ Ireland, $N L$ the Netherlands, $D E$ Germany, $S K$ Slovakia, $H U$ Hungary, $U A$ Ukraine, 0 not any pressure, 1-5 gradient from very low to very high pressure 
Large-scale developments on rivers such as hydro power structures pose a considerable barrier to the movement of fish, and even the smaller constructions such as weirs have an impact on the movement of aquatic species (King et al. 2011). The management of water levels for hydro power schemes has also been shown to have a negative effect on breeding birds (Mitchell 1990), and on certain rare plant species, such as Inula salicina (Martin 1998). Similarly there is evidence that increases in suspended solids, as a direct result of forestry and peat cutting activities, can in some river stretches affect key stages in the life cycles of aquatic species (King et al. 2011), such as salmon spawning, and survival rates of freshwater pearl mussel juveniles (Moorkens 2000).

The Dutch floodplains have fertile soils, which are rich in nutrients. From medieval times onwards tall fruit tree orchards were planted. In the 1960s and 1970s many of the orchards were uprooted for meadows. From 1980 onwards more orchards were reestablished, using more productive low fruit trees. In the lower parts of the floodplains meadows developed or, in the swampy areas, willows grew. Later, the opportunities for tillage improved due to better drainage systems and improved fertilization methods. Horticulture occurred on coarse sandy soils with clay substrate (Jongmans et al. 2013). The river area was also an important source for clay, sand and gravel (De Mulder et al. 2003).

The main biodiversity pressures in Dutch floodplains are related to alterations of hydrological conditions, agriculture, and soil pollution (Table 2). The large-scale building of dykes started in the fourteenth century. Initially, a low embankment was constructed along the border of the river to prevent the flooding of floodplain meadows. To prevent larger floods the much higher winter dykes were constructed, but they regularly broke due to stagnant ice (Van Beusekom 2007). Human encroachment and construction of dykes in the period 1850-2000 resulted in a restriction of discharge capacity and a loss of retention area. The Delta Plan, for which the first ideas were conceived in 1937, was launched. After the 1953 flood, the focus was on the sea defense in the Dutch delta and large dams closed off all river arms from the sea. After a severe flood event in 1995 a programme was initiated to reinforce the inland river dykes. Also, at that time a debate started on the development of water retention areas as flood protection measures. Due to rising sea level and increasing discharge of the rivers, the second Delta Plan was launched in 2008 to prepare the Netherlands for the effects of climate change (Kabat et al. 2009).

The biodiversity of the Dutch floodplains is impoverished, due to reduced natural dynamics and a history of intensive land use. The rivers were important for industry due to their transport potential and the presence of industrial water. This resulted in severely polluted water for many decades and floodplains still have high contamination rates of heavy metals and PCBs. The transport function of the river in combination with flood protection measures resulted in decreased natural dynamics where the river was managed to optimize transport and to minimize flood risks. Land reallotment, accompanied by drainage of marshland and removal of old parcel boundaries added to the decline of biodiversity, in particular hedges and tree rows, typical for diverse cultural riparian landscapes (Agricola et al. 2011).

During the last centuries, floodplains in Germany have largely decreased, and on a national level, just one third of the former floodplains still exist (BMU and BfN 2009). In major catchments, such as the Rhine, Elbe, Danube and Odra, only 10-20\% of the former floodplains are left (Brunotte et al. 2009). Local activities started long before the Middle Ages until 1800, but were scattered and mainly confined around settlements. They have been carried out mostly for the purpose of flood protection of settlements and agricultural areas. Systematic works began around the 1820s with conceptually laid out river bed fixation, and cut-off of side channels, oxbows and meanders, often backed by dyke 
construction (e.g. Tulla's "First Rhine correction" 1828-1878). It was the growing importance of steam boat navigation that triggered the second phase of corrections with the aim of establishing a stable and constantly sufficient water level in the fairway. Measures included groynes and weirs, bank revetments and training walls. Modern river correction was determined by new construction technologies and capabilities, optimizing the waterways for larger navigation capacities and (on the Rhine following the Treaty of Versailles) for the increasing importance of hydropower use.

The main pressure for biodiversity of German floodplains is without doubt the alteration of hydrological conditions, however, there are several additional pressures that are highly relevant (Table 2). Floodplain forests are largely managed for timber extraction with only a few near-natural stands remaining. In addition almost all natural floodplain habitat types are suffering from a loss of dynamics. During the last decades, traditionally used wet meadows and grazing areas have been largely removed or severely altered through intensive agricultural use. Recreational use of floodplains is still increasing in many parts of the country, being a threat to conservation goals as well as a chance for a better public appreciation of the value of floodplains and rivers. The destruction of floodplain habitat is still ongoing. Chances arise from the current restructuring of the classification of navigable waterways for political and financial reasons, which might reveal opportunities for ecological development of certain river and floodplain areas. European WFD and FFHDirectives have triggered widespread activities of responsible authorities, but worries are that structural obstacles and political routine might reduce the needed measures to an inefficient extend. However, a couple of restoration projects have been established recently and could serve as pilots for larger-scale planning.

Demography and land use development in Slovakia was significantly associated with watercourses since the Paleolithic period. First settlements in the Mesolithic and Neolithic followed alluvia of rivers in lowlands and uplands (Rulf 1994). Direct systematic human interventions into the channels of major Slovak rivers date back to the 1770 s, primarily in order to improve navigability and facilitate river transport. The earliest structures of erosion control and flow diversion represent wicker works, fascines, cut trees serving as breakwaters, groynes and bank revetments (Pišút 2006). The main biodiversity pressures in Slovak floodplains are related to alterations of hydrological conditions and alien species (Table 2). In Slovakia, almost one tenth of its territory $\left(4500 \mathrm{~km}^{2}\right)$ has been drained, followed by the construction of water works, regulation of water flow and exploitation of peat, and subsequently leading to the disappearance of wetlands and water ecosystems. Synchronously to infrastructural and housing developments in Slovakia there has been a loss of agricultural and arable land to forests (Klinda and Lieskovská 2010). Agricultural soils are still contaminated at the level of the early $1990 \mathrm{~s}$, and must be further monitored (Klinda and Lieskovská 2010). In terms of river and floodplain regulations, most of the gravel-bed Váh River is regulated with canals, artificial dams and 22 hydropower stations. The Morava and Hron Rivers were straightened between 1930 and 1960 (Holubová et al. 2005). The lower Morava was shortened by more than $10 \mathrm{~km}$ by cutting off 23 meanders. The Lower Hron still maintains a certain degree of freedom to migrate, although flow dynamics and sediment transport are influenced by small hydroelectric power stations and the river shows higher concentrations of suspended load and rapid sedimentation in cut-off meanders (Holubová et al. 2005). Between 1378 and 1528 AD, large avulsions on the Danube River resulted in the abandonment of the $24 \mathrm{~km}$-long lowermost stretch of the Dudváh River (Pišút 2006). At Bratislava the floods of the $1760 \mathrm{~s}$ and $1770 \mathrm{~s}$ triggered a series of channel adjustments and subsequent human interventions, leading to permanent instability of the river channel (Pišút 2002). The modern Danube is the result of the mid- 
flow channelization which happened from 1886 to 1896. Present-day fluvial processes of the Danube are restricted to the riverbed and the floodplain area between the embankments (Szmańda et al. 2008). The sediment transport through the Slovak section of the Danube has been recently affected by the hydropower plants Freudenau (at Vienna, Austria) and Gabčíkovo (Holubová 2000).

The Gabčíkovo-Nagymaros dam project at the Danube resulted in an international conflict between Slovakia and Hungary that was solved at the International Court of Justice in The Hague. The main aim of the project was the improvement of flood protection, river navigability and hydro power production. This construction had an enormous impact on ecological conditions in the Danube floodplains. Many scientific works describe in-depth research and monitoring conducted to elucidate the effects on particular taxonomic groups of plants and animals (Mucha 1999). Several studies demonstrate decline in biological diversity (Bulánková 1995; Krno et al. 1999), which is added to by competition by invasive alien plants (Huba et al. 1998), and the impoverishment of the species inventory of most forest communities (Uherčíková et al. 1999). Also in other Slovakian floodplains, habitat loss and fragmentation has led to the eradication of numerous organisms and the loss of functions which contribute to the preservation of the ecological balance (Klinda and Lieskovská 1998). The problem has increased in the last years, to the extent that a petition was sent to the Slovak Minister of the Environment in 2011 that contained detailed descriptions of the eradication of several fish populations. Also the Tisza River catchment was prone to biodiversity loss due to historic mistakes in floodplain management such as the destruction of large wetland areas (ICPDR 2011).

In Hungary, landscape transformations influencing the present landscape started in the late eighteenth century. Their main driving force was the increased European demand for cereals (Andrásfalvy 2007). Traditional floodplain management had been abandoned and the tillage area could be increased most efficiently by reducing the floodplain area and draining the large lowland marshes and moorlands found in the Tisza basin. For more efficient transportation of crops, rivers had been shortened, and dykes had been built. Wide-scale river regulations started in Hungary in 1846 (Somogyi 2001). Altogether 114 meanders of the Tisza were cut through, shortening the river's whole length by $453 \mathrm{~km}$ (32\%) (Somogyi 2001). The river's fall increased significantly, causing accelerated deepening of the river bed and, at high waters, the filling of the floodways with its own sediments. Outside the newly built dykes, inland waters accumulated, which was mitigated by floodplain drainage with 40,000 km of channels (Somogyi 2001). The majority of the floodways (i.e. the areas between the two dykes) remained under traditional smallholder use (e.g. crops, orchards pastures, meadows and vegetable gardens) until the $1980 \mathrm{~s}$. Its abandonment resulted in a rapid degradation of the semi-natural habitats by the end of the twentieth century. More recently, some regions along the Tisza are losing their human population as a consequence of serious economic and employment difficulties (Mihók et al. 2006; Balázs et al. 2009; Borsos et al. 2010). The main actual pressures for Hungarian floodplain biodiversity are alterations of hydrologic conditions and invasive alien species, but also forestry, agriculture and effects of hydro power stations built outside the Hungarian border are highly relevant (Table 2). Despite all these pressures, three national parks have been established along the Danube, and nationally protected areas or Natura 2000 sites are relatively spacious (Beckmann and Jen 2004). Multilateral dialogues started with the objective of transforming the current river management regime (Sendzimir et al. 2007; Werners et al. 2009; Borsos et al. 2010; Somlyódi 2011).

In the last decades, the drainage of inland waters caused water shortage in some landscapes and contributed to increasing numbers of catastrophic floods in others 
(Somlyódi 2011). The loss of water had simultaneous ecological and social effects. The former shallow water surfaces, temporally inundated pastures and managed fishponds flooded by the Tisza were integral parts of the diverse traditional land use system, causing extreme abundance of fish in the region (Andrásfalvy 2007). This system has been gradually cut back in the sixteenth and seventeenth centuries, and ended totally with the construction of the dykes (Andrásfalvy 2007). The landscape change decimated not only the fish stocks but also the once famously rich avifauna: based on historical data, by the twentieth century nesting of white pelicans (Pelecanus onocrotalus) and common cranes (Grus grus) ceased, and the numbers of ducks, geese, herons, pygmy cormorants (Phalacrocorax pygmaeus), great bustards (Otis tarda) and saker falcons (Falco cherrug) became markedly less (Ecsedi 2004). Significant increases in the number of alien fish, reptiles and mollusks started at the end of the nineteenth century, and currently exceed 40 species in the Danube (Bódis et al. 2012). The proportion of alien species in the fish fauna in the larger rivers is 10-16 \% (Erös 2007). Floodplain meadows, tall herb communities and marshes shrank to a fraction of their original extent. Meadows isolated from the floods have been transformed into arable land or dry short-grass steppe (Molnár and Borhidi 2003). In the last decades habitat quality and regeneration potential of floodplain habitats is rapidly decreasing due to the expansion of invasive species and land abandonment (BottaDukát 2008; Molnár et al. 2008b; Biró 2009).

Also in the Ukraine, large rivers, especially Dnieper, Severski Donets, Southern Bug, and their main tributaries are under constant anthropogenic influence. From 1930 to 1980 the main objective of the national economy was the river regulation for water engineering and land improvement. In the Dnieper storage reservoir cascade, for instance, consists of 1,103 large water storage reservoirs and 48,000 smaller artificial ponds (Gusieva 2012). The river regulation history in Ukraine was initiated in 1927, when the construction of Dniprovska hydropower station began, which was finished in 1935. From 1950 to 1975, five more water reservoirs were created and the Dnieper flow became completely regulated (Denisova et al. 1981). On the Southern Bug, the distinctive feature is the intense regulation of flow by 197 water basins and almost 7000 ponds with a total volume of $1.5 \mathrm{~km}^{3}$; currently most of these hydroelectric stations are ruins. The riverbed of the Ukrainian part of Seversky Donets is dammed three times. Many tributaries also have multiple dams; eight are located near Kharkiv, with more than ten around Sloviansk. In river basins of the middle-sized rivers of the Ukraine some small water reservoirs and many ponds were constructed since the $1960 \mathrm{~s}$ (Vyshnevsky et al. 2011). By 1990 the reservoirs' area made up 761,000 ha (1.26\% of the country territory); $70 \%$ of this inundated areas were former floodplains (Anonymous 2004). The most important pressures for Ukrainian floodplain biodiversity are alteration of hydrologic conditions and invasive alien species, but also settlements and industrial infrastructure, water pollution and eutrophication, hydropower, and mining and quarrying must be considered as highly relevant (Table 2).

The main environmental effect of river regulation was that huge areas of floodplains became permanently flooded, sometimes, also the second terraces of river valleys (Avakjan and Sharapov 1968; Vendrov 1970; Vyshnevsky et al. 2011). The landflood resulted in total destruction of natural vegetation and ecosystems of floodplains and in the occurrence of large areas of impoundments having quite a weak current. For 3-4 months per year, 80-90\% of the Dnieper water area blooms and biomass of cyanobacteria averages about $60-100 \mathrm{~g} / \mathrm{m}^{3}$ (Yatsyk et al. 2007). The areas closed to the reservoirs are depleted wetlands, which are frequently protected by dams (Vyshnevsky et al. 2011). The flow regulation at the middle stretches leads to permanent flooding of bottomland and disturbance of their hydrological regime. Water levels are kept rather low in times of floods to protect the 
hydropower dams from destruction. The absence of high water changed the regime that had existed for millennia, and thereby reduced the removal of excessive organic matter from inundated reservoirs and diminished the beneficial natural fertilization of the floodplain soil by floods. Small rivers, which are highly relevant and form $60 \%$ of the water resources of Ukraine, are also regulated and spring riverbed flushing is artificially reduced. In conjunction with the ploughing of land in river valleys this leads to inevitable silting and overgrowing of water bodies with aero-aquatic plants (Baranovsky et al. 2001).

As a result of all these developments, natural floodplain ecosystems changed considerably. Meadows, woods and arable lands were flooded, hydrology and hydrochemistry were altered, the soils were impounded, the vegetation changed and initial high level of biodiversity decreased strongly (Akinfiev 1889; Baranovsky and Aleksandrova 2005; Baranovsky et al. 2007). For instance in the area of the Dniprovske reservoir, 795 higher plant species were registered in the floodplain before construction works started. 150 of these species disappeared and many others became rare, whereas 90 alien species invaded the area (Baranovsky 2000). Naturally diverse woodland ecosystems of floodplains (Belgard 1950) changed into simple communities with reduced biodiversity. Forest ecosystems covering and surrounding Ukrainian floodplains in the past (Nikolaenko 1980), were largely degenerated or lost and replaced by meadows, pastures and tillage. The incessant destruction of the smaller rivers became one of the biggest regional environmental problems entailing sediment deposition in the larger rivers, summer bloom and fish kills caused by suffocation (Baranovsky et al. 2001). In the Dnieper basin the ecological conditions of the majority of small rivers are qualified either as catastrophic or as bad (Zagubizhenko et al. 2002; Yatsyk et al. 2007). Ecological changes include increased sedimentation and development of reeds (Phragmities australis (Cav.) Trin. ex Steud) that transformed a natural community into a simpler and depauperate one.

\section{Response: floodplain conservation and restoration, multifunctional floodplain management and evidence for effects on biodiversity}

The legislation and implementation in terms of floodplain management of all the mentioned countries except the Ukraine have been similarly influenced by their membership in the EU and the related policy framework such as the WFD, the Flood Protection Directive, the Habitats Directive, the Birds Directive, as well as the related financial instruments (in particular LIFE, LIFE + and the funds of the EU's Regional Policy) (Mauerhofer 2010).

The management of floodplains in Ireland is still focused on flood alleviation, with the building of embankments and other flood defenses being a common approach. There is also still an emphasis on the drainage of frequently flooded areas, rather than reinstating natural wetlands to slow down the rate of percolation of water through the system and therefore to slow down the rate at which the water reaches the rivers. The most common example of multifunctionality is likely the construction of weirs designed to ensure that they perform the role of water flow control while also facilitating the movement of fish and other aquatic species through the river system.

Small local-led initiatives funded by the EU Life programme have been the basis of several river restoration projects in Ireland which have sought to take a multifunctional approach to management. One such restoration project is MulkearLIFE (www. mulkearLIFE.com), which aims to restore $21.5 \mathrm{~km}$ of degraded habitats along stretches of the Mulkear River, which drains a total catchment area of $650 \mathrm{~km}^{2}$. The main focus is to provide habitat for sea lamprey (Petromyzon marinus), Atlantic salmon (Salmo salar) and European otter (Lutra lutra). The project addresses multifunctionality by engaging with 
fisheries, farmers and the local community to achieve its multiple goals of improved water quality, locating alternative sustainable water sources for cattle, control of invasive species, and fostering a greater awareness locally of conservation issues relating to the river, its biodiversity and the ecosystem services that it supplies. A similar EU Life project has run in Duhallow, Co. Cork. Both of these projects have occurred in Special Areas of Conservation designated for their river habitats and associated species. In another project in County Kerry, biodiversity enhancement works to the River Lee at Ballyseedy Wood, an Annex I alluvial woodland, were recommended by O'Neill et al. (2008). Funding was received in 2012 and the project is expected to lead to improved water quality and enhanced conditions for spawning salmonids, with benefits expected for overall biodiversity and recreational fishing to the area. The Lough Melvin catchment management plan (Campbell and Foy 2008) is another project that applies a multifunctional approach, with the main aim being to reduce nutrient levels within the catchment. It has 22 recommendations covering impacts such as agriculture, forestry and wastewater from housing. Some of the most notable recommendations include (i) education programmes for landowners whose activities impact the environment, (ii) policies that restrict one-off housing in sensitive parts of the catchment, (iii) initiatives to deal with alien invasive species such as northern pike (Esox lucio), (iv) screening of forestry operations in the catchment for appropriate assessment under Article 6 of the Habitats Directive, (v) a package of agrienvironment measures for the Lough Melvin catchment, and (vi) active management of riparian forest buffer zones to reduce the impact of neighbouring clear-felling.

To our knowledge there is no Irish evidence for biodiversity effects of multifunctional floodplains. However, evidence for failure of monofunctional conservation projects is available (Maher et al. 2011) and based thereon recommendations for multifunctional approaches were derived that include considering the needs of all stakeholder groups including conservation organizations, farmers and the tourism and leisure industry (Maher 2013).

In the Netherlands, the approach towards floodplains changed over the last two decades. The overall aim is to increase multifunctionality, with flood protection and increasing biodiversity being among the most important functions (Fliervoet et al. 2013), another important function is tourism. In the same period, water quality improved significantly due to the raising of environmental standards and international cooperation such as the International Rhine Committee. Through application of a mixed centralized-decentralized governance approach, the Room for River programme has dealt with governance pitfalls related to centralized planning approaches that previously impeded integrated water management (Rijke et al. 2012).

Planning for more natural floodplain development began in 1986, when landscape architects and spatial planners launched the development plan 'Plan Stork' that set into motion a school of planners and ecologists that promoted MFM. WWF Netherlands adopted this approach and a foundation 'Ark' was established with the aim of restoring natural processes; the programme was in line with the Dutch conservation programme (Kurstjens and Peters 2012b). It was a kind of new paradigm, which coincided also with the Ecological Network approach which was since 1991 leading for the Dutch conservation policy (Van der Sluis et al. 2012). In 1993 and 1995 the water levels were extremely high, and a quarter of a million people had to be evacuated. Extreme high river discharges are predicted to occur more frequently in the future and therefore it was decided to increase the discharge capacity of the rivers. The Government approved the Room for the River Programme in 2007 for the Rhine. This plan has three objectives (i) by 2015 the branches of the Rhine must be able to cope with a discharge capacity of $16,000 \mathrm{~m}^{3} / \mathrm{s}$ without flooding; 
(ii) the measures implemented to increase safety must also improve the overall environmental quality of the river region; and (iii) the additional retention area for the river, required to cope with higher discharges, will remain permanently available for this purpose. In total, nine options are considered to enlarge riverbed and floodplains, including dyke relocation, depoldering, and water storage (Fig. 2). The approaches presented in this figure are rather advanced examples of eco-engineering, and are expected to have different impacts on multifunctionality, natural dynamics, and biodiversity (Table 3). Of the 700 potential projects that were identified in the area of the Rhine and the Ijssel, 39 were selected (Rijke et al. 2012), with 35 projects to be implemented in the period 1995-2015. For the River Meuse, the Meuse Works Programme, was officially initiated in 1997 and scheduled for completion by 2018 . The aims were similar to the ones for the Rhine: fewer floods, better navigability, a wider river bed and a more natural river valley. In total, 1800 ha are to be converted to nature restoration areas, and 52 projects are or have been

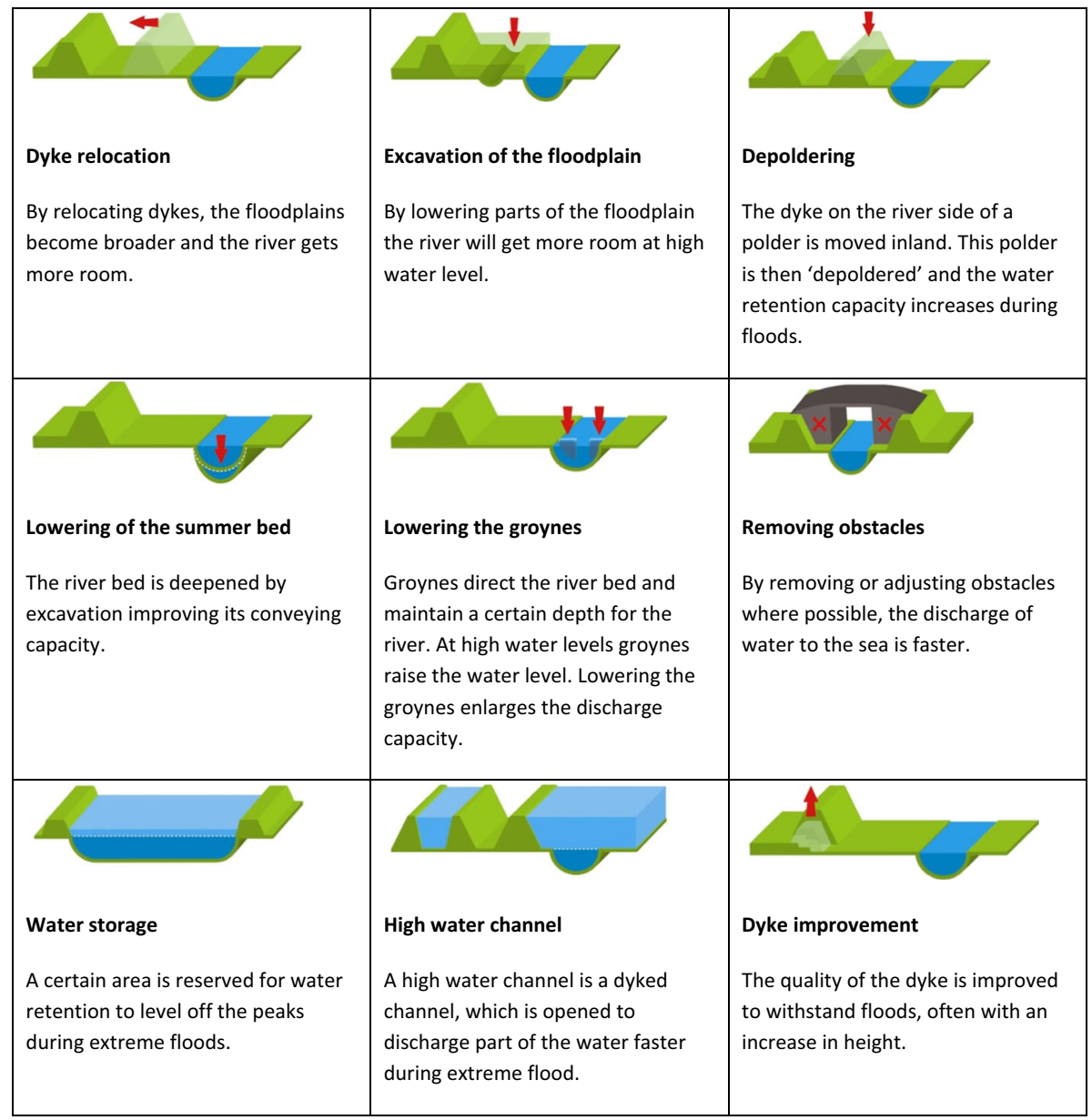

Fig. 2 Nine approaches of river restoration by reconstruction of the floodplains and the river bed (based on: the Dutch 'Room for the River' Programme: http://www.ruimtevoorderivier.nl) 
Table 3 Impacts of the different measures of the Dutch 'Room for the River' Programme on multifunctional use, biodiversity, natural dynamics, and flood protection (as estimated by the authors of this study)

\begin{tabular}{|c|c|c|c|c|c|c|}
\hline \multirow[t]{2}{*}{ Measure } & \multirow{2}{*}{$\begin{array}{l}\text { Number of projects } \\
\text { (Rijn \& Ijssel) }\end{array}$} & \multicolumn{5}{|c|}{ Expected impact } \\
\hline & & $\begin{array}{l}\text { Multi- } \\
\text { functional } \\
\text { use }\end{array}$ & $\begin{array}{l}\text { Bio- } \\
\text { diversity }\end{array}$ & $\begin{array}{l}\text { Natural } \\
\text { dynamics }\end{array}$ & $\begin{array}{l}\text { Landscape } \\
\text { diversity }\end{array}$ & $\begin{array}{l}\text { Flood } \\
\text { protection }\end{array}$ \\
\hline Dyke relocation & 5 & 0 & + & + & \pm & + \\
\hline $\begin{array}{l}\text { Excavation of the } \\
\text { floodplain }\end{array}$ & 12 & + & + & + & + & + \\
\hline Depoldering & 2 & - & + & + & \pm & + \\
\hline $\begin{array}{l}\text { Lowering of the } \\
\text { summer bed }\end{array}$ & 1 & 0 & 0 & 0 & \pm & + \\
\hline $\begin{array}{l}\text { Lowering the } \\
\text { groynes }\end{array}$ & 3 & 0 & 0 & 0 & 0 & + \\
\hline $\begin{array}{l}\text { Removing } \\
\text { obstacles }\end{array}$ & 1 & 0 & 0 & + & \pm & + \\
\hline Water storage & 1 & + & 0 & 0 & 0 & + \\
\hline $\begin{array}{l}\text { High water } \\
\text { channel }\end{array}$ & 1 & - & 0 & 0 & - & - \\
\hline $\begin{array}{l}\text { Dyke } \\
\text { improvement }\end{array}$ & 7 & 0 & 0 & 0 & - & - \\
\hline
\end{tabular}

+ positive, \pm both positive and negative, 0 neutral, - negative

executed in the Meuse area ${ }^{1}$; they focus on dyke improvement, tourism and grazing management.

Nature restoration projects along the Meuse were executed from 1995 onwards (Kurstjens and Peters 2011). The Meuse floodplains changed from an area which was mostly farmed or used for mineral extraction to a multifunctional area aimed at flood security, natural functions and recreation. The extent of natural floodplain habitats along the Meuse increased from 100 ha in 1990 to 1500 ha in 2006 (Kurstjens and Peters 2011), and the number of such areas increased from four to 42. An evaluation showed the following success for nature restoration (Kurstjens and Peters 2012a,b): (i) $40 \%$ of the plant species benefited from the creation of floodplain meadows, scrub, and forest on former farmlands; (ii) increased river dynamics resulted in new habitats as well as the establishment of new plant populations; (iii) through excavation, pioneer situations were created; (iv) dispersal of seeds was enhanced by large grazing animals; and (vi) water quality improved for aquatic species. A strong increase in the riverine flora happened particularly in locations with sandy soils, where sand dynamics are a crucial factor. While increased dynamics also resulted in the loss of species that depend on stable situations, the overall impact was an increase in species diversity. Mammal indicator species such as Eurasian beaver (Castor fiber), European otter and European badger (Meles meles) returned. They had been absent from the rivers since the $1960 \mathrm{~s}$, or extinct in Dutch territory in the case of the Beaver. For birds, the situation of pioneer species as well as species from softwood and hardwood forests and colony breeders improved significantly. However, marshland and farmland birds have not recovered yet or are still declining,

\footnotetext{
${ }_{1}$ http://www.rijkswaterstaat.nl/water/plannen_en_projecten/vaarwegen/maas/maas_maaswerken/.
} 
despite active restoration plans (Kurstjens and Peters 2012a). Of the amphibian species the Great crested newt (Triturus cristatus) occurs along the different branches of the Rhine (Creemers 1994), and among reptiles, the Grass snake (Natix natrix) shows a positive trend along the natural floodplains of the Lower Rhine. The populations of fish of running water are increasing because of the improved water quality of the Rhine and the construction of side channels. Even fish species which were extinct have returned, such as the Atlantic salmon, for which conservation plans were implemented and many rivers were made passable (Van der Sluis et al. 2004). Recovery of butterflies is slow; the two areas with the highest species density are the Blauwe-Kamer and the Duursche Waarden (Online Ressource 1). The number of dragonflies has much increased due to the improved water quality, climate change and increased biotope diversity, especially in the Blauwe Kamer and the Duursche Waarden. Grasshoppers have also benefited. For some species climate warming is a relevant factor in recovery (Warren et al. 2001).

In Germany, multifunctionality is, to a very limited extent, included in various legal regulations. For instance, the Federal Water Act demands water managers to preserve, protect and even improve natural habitat, to preserve and improve current and potential uses of water resources, thus to manage resources beyond water in a sustainable manner. This is not yet multifunctional, but is intended at least to open the scope of authorities' actions in order to comply with other sectors' objectives. In particular, conservation goals have increasingly been included in other sectoral laws.

River restoration occurred mostly through the implementation of projects along smaller rivers and streams within the regular river maintenance "Gewässerunterhaltung", many of these activities being a result of successful WFD implementation. Furthermore, several large projects have been carried out which tackled multiple aspects at a time, mostly flood protection and nature conservation, e.g. at Elbe, Danube, Rhine (again mostly in connection with the WFD), but also recreational areas in urban settings (e.g. Emscher project, Isar in Munich).

On a national level, the Federal Agency for Nature Conservation has financed restoration projects for about 15 years to enhance both nature conservation and flood protection. Moreover, a number of federal state programmes have been implemented primarily to increase the level of flood protection, especially with regard to climate change aspects. Nature conservation aspects are included to different extents in such programmes. For example, the Integrated Rhine Programme of Baden-Wuerttemberg started out as a combination of flood protection and floodplain conservation; the latter aspect has unfortunately been largely abandoned in the course of the programme. Synergic benefits of river and floodplain restoration e.g. mitigation of flood risk or of consequences of climate change, are far from being fully exploited and multiple environmental effects are still neglected. The ecosystem approach can help to provide a long-ranging delivery of natural resources and services depending on their sustainable use (BMU 2008).

Conflicts on future floodplain management regimes have emerged in cases where flood managers planned to use near-natural floodplain areas as controlled flood retention polders, which would involve an intentional, rapid filling of floodplain areas with water abstracted from the river during the peak phases of floods. Hydrologists consider this type of targeted polder filling as the most effective way of lowering peak flood levels in downstream sections of a river (Müller 2010). Such polder filling is accompanied by rapid increases in water levels in distinct floodplain areas enclosed by dykes on all sides with no significant through-flow of water. The obtainable flood peak reduction strongly depends on the shape of the flood hydrograph and its predictability (CRUE 2008; Förster 2008). Polders impose severe detrimental effects on the affected biocoenosis such as oxygen deficiency and 
sedimentation, their infrequent flooding impeding the development of flood-adapted species communities (Dister 1992; Armbruster et al. 2006).

A number of studies in Germany supports the hypothesis, that river and floodplain restoration measures increases biodiversity (Kail et al. 2015), with positive effects being more pronounced in terrestrial than in aquatic habitat types (UBA 2014). Whereas restoration successes prevail, neutral and even negative effects of restoration measures have also been reported in particular for aquatic organisms (Sundermann et al. 2011; Lorenz et al. 2012). A research project commissioned by the German Federal Agency for Nature Conservation revealed that restoration projects have been realized within some $5 \%$ of the floodplains in Germany (BfN 2013). These cover about 40 projects alongside bigger rivers, in which approximately 4000 ha of floodplains have been reconnected by dyke and dam relocation in the last 15 years (BfN 2013). Although there is yet no suitable systematic study covering a representative number of restoration projects within smaller streams and catchments, there is some evidence that, due to restoration and subsequent management changes, the biodiversity value of the restored floodplains can significantly increase. Lüderitz et al. (2011) investigated the development of biodiversity during a large-scale river restoration project with a restored section of about $18 \mathrm{~km}$ compared to adjacent non-restored sectors. The study showed that species numbers were two to three times higher in the restored reaches. This increase applied to all taxonomic groups, but was particularly significant for Odonata, Trichoptera, Plecoptera and Ephemeroptera (Lüderitz et al. 2011). However, far more research is needed to analyze, monitor and evaluate further biodiversity effects of MFM.

In Slovakia, conservation of inland water ecosystems is one of several activities within the implementation of the Convention on Biological Diversity and the Ramsar Convention. Besides the National Biodiversity Strategy and its components related to ecosystem protection, Slovakia additionally adopted a National Programme on wetlands (according to the Ramsar Convention) and a programme on the restoration of river banks. Also an Integrated River Basin Management and a Land Restoration Programme have been implemented and restoration of water courses, bank vegetation and natural water regimes was performed.

One of the successful projects dealing with the floodplain restoration was the LIFE-project 'Conservation and management of Danube floodplain forests'. The objective was to conserve the last remaining natural floodplain forests in the Slovak part of the Danube floodplain and to introduce sustainable forest management in the area (BROZ2003). Project actions focused on halting the loss of natural floodplain forest habitats by improving forest management plans, applying ecological forest management measures, planting of native trees, designation of new nature reserves, land purchase and lease for nature conservation purposes and raising awareness of the general public, decision makers and other key stakeholders.

The productivity of arable fields in the floodplains is several times lower than the production from meadows (Šeffer and Stanová 1998). Intensive agricultural practices are not sustainable and polluted together with industrial developments the Morava river and its tributaries (Šeffer and Stanová 1998). The Danube and its floodplains play a very important multifunctional role for hydropower, transport, flood protection, biodiversity conservation, and creation of natural flow regimes, purification and remediation, and recreation and tourism (Lisický and Mucha 2003). The Váh River provides a significant supply of electric power; however, flood protection is also an important issue, as well as water provision for irrigation of agricultural areas, and tourism and recreation.

Slovakian floodplains host two large Protected Landscape Areas (PLAs) (Latorica and Dunajské Luhy), 14 Ramsar sites and more than 200 small protected areas (National Natural Reserves, Natural Reserves and Protected Areas). Beside flood protection, MFM often implies biodiversity conservation, but also of importance are recreation and tourism, 
namely hiking, swimming and sailing. Particular examples for MFM are the floodplains of the partly still meandering Morava River that include riverine forests and flooded meadows and are one of the most valuable wetland areas in Central Europe (Ruzickova et al. 2004). The 90 river kilometres that are forming the boarder to Austria are an important element of the European Green Belt (Zmelik et al. 2011) and the Alpine Carpathian Corridor (Strohmaier et al. 2008). Restoration measures such as reconnection of meanders with the river system, increase of flow dynamics, excavation of sediment deposits from meanders, and special mowing scheme are proposed and partly implemented to conserve the natural values and the derived human benefits (Rybanič et al. 1999; Holubová and Steiner 2011). Hay production has shown to significantly affect biodiversity because regularly mowed meadows maintain high vascular plant diversity including rare and endangered species, and nitrogen abatement has also positive effects on the plant communities (Šeffer and Stanová 1999). After 1990, arable fields in active floodplain areas were restored back to meadows to increase biodiversity and to decrease river pollution (Šeffer et al. 1999). The results show that the re-establishment of floodplain meadow communities can occur quickly and that rare species can reestablish and persist (Šeffer et al. 1999).

River and floodplain restoration projects in Hungary mostly target the reconstruction of oxbows, grasslands on abandoned arable fields, or pastures and meadows invaded by bastard indigo (Amorpha fruticosa). Grazing, mowing, grassland establishment, clearing of invasive shrubs and trees and restoration of the water balance support their biodiversity conservation functions. The keeping of a traditional cattle breed, the Hungarian grey cattle, has also a gene preservation function in Hungary. Information boards and educational trails in the restored areas serve for recreation and environmental education realizing the multifunctionality in the restoration projects. Some projects have implemented further multifunctionality, like social and economic benefits, producing new jobs or income from livestock and hay production (e.g. projects in Tiszatarján, ${ }^{2}$ Tiszaalpár\&Mártély, ${ }^{3}$ Nagykörü, ${ }^{4}$ Esztergom\&Ipoly-völgy $\left.{ }^{5}\right)$. During these projects inhabitants have been involved in the management and clearing of invasive species in the floodplain, by which further jobs have been created, fuel wood for winter has been provided, and the heating of public institutional buildings was realized. Traditional fishery management based on the natural dynamics of the river was reconstructed in Nagykörü. The renewal of traditional orchards was realized by the project at Mártély area. By reconstructing former sidechannels ${ }^{6}$ traditional landscape scenery and land-use types, and aesthetic and recreation functions were implemented in all MFM projects project. One recently started regional

\footnotetext{
2 OEMN ("One Europe, More Nature/Funded by WWF-Netherlands") project; implemented in Tiszatarján; coordinated by WWF-Hungary http://wwf.panda.org/what_we_do/where_we_work/project/projects_in_ depth/one_europe_more_nature/sites/tisza_floodplains_hungary/

http://d2ouvy59p0dg6k.cloudfront.net/downloads/rz_oemn_factsheet_tisza.pdf.

3 KIOP project/EU Structural Fund; implemented in Tiszaalpár and Mártély, Tisza-river; coordinated by Kiskunság National Park Directorate 2005-2008. http://www.kontyvirag.hu/adat/tartalom/ elohelyrekonstrukcio/\%C3\%891\%C5\%91helyrekonstrukci\%C3\%B3-kiadv\%C3\%A1ny.pdf.

4 TiszaLIFE project; LIFE/EU; implemented in Nagykörü, Tisza-river; coordinated by WWF-Hungary 2001-2005 http://www.tiszalife.hu/en/life_program.html.

5 HUSK project/EU Cross-border Cooperation Programme 2007-2013; implemented along the Danube and Ipoly-river; coordinated by Duna-Ipoly National Park Directorate 2012-2015. http://www.dunaipoly.hu/hu/ palyazataink/item?id=4.

6 "Három folyó = Egy cél" project; IPA/EU Croatian-Hungarian cross-border project; implemented along Belső-Béda, Danube; coordinated by Duna-Drava National Park Directorate 2014-2015.
} 
scale programme ${ }^{7}$ aims at rural development in addition to habitat rehabilitations along the river Dráva (Elek et al. 2013). Cooperation with neighboring countries is remarkable in several floodplain rehabilitations and the use of EU and national ministry funds was widespread among the Hungarian MFM and floodplain rehabilitation projects.

During most projects diverse landscape structure has recovered, and the quality and naturalness of habitats has been continuously increasing. Abandoned pastures, meadows, arable fields, and invasive bush and tree stands have mostly been changed into regenerating floodplain meadows and native woodlands. Extensive grazing helped grassland regeneration and decreased cover of bastard indigo in almost all cases. Effects on biodiversity are monitored usually by nature protection managers of the National Park Directorates. However, systematic monitoring was implemented in only some of these projects. In two cases monitoring was based on phytosociological or zoological relevés (Demény and Keresztessy 2007; Margóczi and Roboz 2011). In these two areas (Nagykörü and Tiszaalpár) bird monitoring was also conducted. According to these observations White-tailed Eagles (Haliaeetus albicilla) established territories in both areas, and significant numbers of Pygmy Cormorants (Phalacrocorax pygmeus), herons, shorebirds and ducks were nesting and gathering on the lakes. Glossy Ibis (Plegadis falcinellus), Black Stork (Ciconia nigra) and Whiskered Tern (Chlidonias hybrid) were observed on several occasions (Rimóczi, unpubl. data; http://www.tiszalife.hu/en/life_program.html; Bártol 2008; Bártol unpubl. data). In Nagykörü the occurrence of 22 fish species (including two protected species, Misgurnus fossilis and Rhodeus sericeus) was recorded in the new traditionally managed fishpond (Demény and Keresztessy 2007). After the flood of 2006, 20-30 young fish $/ \mathrm{m}^{3}$ were found in the lake. In autumn more than 2000 well-developed pikes were released into the river, but the reproduction of invasive fish species still seems to be a problem (Demény and Keresztessy 2007).

During restoration of an alluvial grassland the bastard indigo could be successfully suppressed by grazing or systematic mowing, but it can hardly be entirely eradicated despite interventions every year (Szigetvári 2002; Margóczi and Roboz 2011; Lájer 2012; Sallainé Kapocsi and Danyik 2015). In some of the ancient grasslands, stands of characteristic alluvial species (Orchis laxiflora subsp. laxiflora, Leucanthemella serotina, Clematis integrifolia and Iris spuria) became considerably stronger (Bártol 2008; Margóczi and Roboz 2011). The conversion of croplands and abandoned arable fields into grasslands had varying results. Regeneration was usually slow. In some cases disturbancetolerant species or weeds became dominant, in other places generalist monocots like Alopecurus pratensis, Poa trivialis, Bolboschoenus maritimus or Elymus repens increased significantly, or occasionally rare annual floodplain species with high nature value (Vicia biennis, Astragalus contortuplicatus) appeared in large numbers (Margóczi and Roboz 2011; Bártol 2008). Habitat naturalness increased by the transformation of woods of nonnative species and arable fields into native forests, where young stands of Populus nigra, Fraxinus angustifolia subsp. pannonica, Quercus robur and Ulmus laevis had been established in Tiszaalpár and Mártély. After the oxbow restorations (e.g. river deposits had been removed, floodgates had been built) the increased water level (by 30-40 cm) also improved habitat quality and naturalness, and diverse hydrophyte and wetland habitats developed (Bártol 2008).

Conservation of floodplains in Ukraine is ensured for 33 Ramsar cites by the implementation of the Ramsar Convention. The majority of the Ukrainian Ramsar sites are

7 Complex rural development strategy called Ös-Dráva programme; implemented along the Drava river; 2007-2013 and 2014-2020 http://www.osdrava.hu/. 
conserved as national nature parks, nature reserves, biosphere reserves and regional landscape parks. In 2009-2012, floodplains were restored by dyke removal and other measures within the Ramsar Sites "Stokhid River Floodplains" and "Prypiat River Floodplains." (Anonymous 2012).

Long-term research of plant diversity of rivers of the Dnieper and Southern Bug basins allowed the development of a set of measures for restoration of natural conditions and biodiversity of the floodplains of the Steppe zone (Baranovsky 2000, 2005, 2005; Loza et al. 2004; Baranovsky et al. 2007). Long-term cooperation of scientists with basin authorities and waterworks allowed restoration studies and projects to be realized in the Dnieper basin: (i) hydro-engineering (dredging) works carried out under the control of ecologists (no river-channel straightening was allowed) with conservation of the areas with especially valuable flora and fauna, (ii) restoration of newly formed bank slopes with meadow grasses, and (iii) plantation of forest shelter along river banks with selected species forming a sustainable ecosystem with diverse communities of plants, animals and fungi (Baranovsky et al. 2007, 2009a, 2009c). Thus, floodplain forests recovered providing a high water-regulation capacity (cf. Tkachenko 1975) and formed a microclimate that promotes an increase in biodiversity (Grytsan 2000; Kulik et al. 2008).

Also Dnipropetrovsk National University and the State Regional Planning and Survey Institute "Dniprogiprovodhoz" are conducting multifunctional projects on environmental rehabilitation and biodiversity restoration of rivers (Baranovsky et al. 2013). One of the examples of such works is the project 'Restoration of a hydrological regimen of the wetland Diovsky plavni'. The project cleared channels of impounded floodplains of the right bank of Dnieper River above Dnipropetrovsk (the upper part of the Dniprovske water reservoir). As a result of the project, an increase in biodiversity was noted in the water bodies and the floodplain (Grytsan et al. 2006) during the first period, mainly for plants. Another example is the project 'Restoration of a hydrological regime of the Orel River' at the border of Dnipropetrovsk and Poltava provinces. Riverside forest shelter belts of white willow (Salix alba) were created. The subsequent increase in plant diversity on the floodplain was confirmed (Baranovsky et al. 2009b).

The main purpose of the mentioned projects was to decrease the ground water level of the adjacent populated and agriculture lands for economic reasons. However, thereby the rehabilitation of ecosystems and biodiversity was realized as well. Successful small multifunctional projects of the Dniester floodplain rehabilitation are reported by Rusev and Ruseva (2000). The projects included measures such as clearance of small sections of the river bed, opening small gaps in dykes with subsequent renewal of flowage between water bodies, the reclamation of the riverside slopes, and the plantations of trees. The result was a restoration of the hydrological regime, a revitalization of the floodplain's meadows and increases in biodiversity and population abundance: the populations of fish, geese, herons, glossy ibises, ducks and waders increased (Rusev 2003).

\section{Discussion}

\section{Multifunctional management of European floodplains}

Multifunctional use of floodplains has become an important management strategy in some countries, in particular in The Netherlands and Hungary. This trend is in agreement with developments in floodplains and deltas in Europe (Hein et al. 2016) and in other continents 
(Wesselink et al. 2015). Multifunctional approaches mainly show success where a large range of stakeholders with diverse expertise and interests are involved in all stages of planning and implementation of projects. It is recognized that such participatory processes are beneficial for environmental resource management (EC 2005; Paavola et al. 2009; Silva et al. 2009). The mixed centralized-decentralized approach in the Netherlands has been effective though in realizing many water safety projects through the stakeholders involved, partly funded through industries. However, it was less effective in the used governance model, and stakeholders views and public support have been questioned (Fliervoet et al. 2013). In Hungary, projects aiming at rehabilitation of biodiversity by clearing invasive alien species have become frequent. In some projects multifunctionality was realized by implementing other functions like economic, social, educational and touristic ones. Although the involvement of local stakeholders and inhabitants at all stages of the process is not yet widespread, the role of common works, public involvement and a multifunctional approach are generally increasing in Hungarian projects. As enhancing biodiversity is an important goal, either the National Park Directorates or the WWF plays a leadership role in almost all projects. Due to projects focusing on areas invaded by alien species, habitat quality and abundance of characteristic floodplain species has generally increased, although systematic monitoring has been scarce. In those projects that aim to restore water balance of oxbows or inner dyke wetlands, diversity of fish and avifauna increased, large numbers of migrating birds appeared, and nesting of some rare and protected birds was observed (Demény and Keresztessy 2007; Bártol 2008). This is in concordance with conservation success of similar restoration projects from neighboring countries such as Austria (Funk et al. 2009; Schmutz et al. 2014).

Still in other cases efficient mechanisms are lacking and a big gap remains between the rhetoric on participation and the real-life implementation of participatory processes (Rauschmayer et al. 2009). Administrative structures often support the subsequent standstill at all levels: The sectoral organization of national governmental structures has its analogy in the organization of the European Administration and many European policies are not fostering multifunctionality. In Ireland, for instance, it is recognized that MFM is the best way to manage rivers and their associated floodplains, but there are only a few examples of this recognition being put into practice. There needs to be a more concerted effort by government agencies to promote multifunctional management and to monitor the effects of such management on biodiversity. Also in Germany, multifunctionality is still poorly represented in floodplain management. Programmes and measures which are mostly initiated by governmental institutions are reflecting that public administration is structured in sectors (Nielsen et al. 2013): entities responsible for water management are largely focusing on their respective goals (e.g. flood protection, land use, navigability). Measures initiated by conservation units are focusing mainly on conservation issues rather than on integrated or multifunctional landscape development. This has changed to some extent with the implementation of the WFD, but there is still a general lack of interdisciplinary measures, and this is unlikely to improve in the face of tightening budgets and reduced resource allocation (Nielsen et al. 2013). The importance of the WFD for floodplain management can hardly be overestimated, since no other EU-strategy has triggered so many waterbody related measures (Čimborová and Bartková 2014). However, the WFD focuses largely on ecological improvements, and related projects sometimes do not constitute multifunctional approaches. Even though in its implementation the scope has broadened and positive side effects do touch other sectors as well, future amendments of the directive should be used to further broaden its scope and install multifunctionality as it is already discussed for ecosystem services. Concerning other EU directives, the Habitat 
Directive similarly targets the safeguarding of natural values and conservation issues and widely lacks a multifunctional background. This could only be changed by broadening its focus as suggested for the WFD. The modern state of floodplains in Ukraine, the only investigated country which has not been influenced by the EU and its WFD, is still determined by long-term anthropogenic influences. The implementation of evidence-based management actions to improve floodplain functionality and to restore lost biodiversity are still few. Multifunctionality as a sustainable management approach for floodplains receives little attention from Ukrainian policy makers and authorities. In the Ukraine, there is much scientific literature on both floodplain biodiversity (Gasso 2009; Banik and Korshunov 2014) and floodplain management (Stefanyshin 2010), but it is often not related to each other and research assessing the biodiversity effects of management interventions would be highly required for many areas (Baranovsky et al. 2013).

When comparing the situation in the investigated countries, an interesting pattern of regional differences in current management goals and approaches occurs (Table 4). Whereas flood protection is the top priority in floodplain management in the Netherlands, Ireland, and Hungary, the focus is set on navigation in Germany, while Slovakia and Ukraine seem to have a more mixed agenda. MFM seems to be possible under all three strategies but it is showing differences in size and number of projects, which is mainly linked to the particular management structure for water in the countries, ranging from centralized national responsibility in the Netherlands and Hungary to provincial governance in Germany and Ireland and a rather mixed situation in Slovakia and the Ukraine (Table 4). In the Netherlands the approach based on the development of networks of natural areas resulted in a network of wetlands, riverine forests and natural grasslands. This has also an important scale effect, in that the areas together, the ecological network, allows for the (re-)establishment of wildlife populations. The ecological network is therefore essential in realizing sufficient habitat for wildlife populations. This was achieved through the cooperation between the Ministry and environmental research institutes, but also through funding mechanisms from the Provinces and mineral extraction industries. Regarding the management approaches, there is a compelling common set of measures all over Europe, targeting not only the restoration of hydrological connectivity at different scales, but also the adaptation and extensification of land use in flood plains as a precautionary principle.

\section{Multifunctional floodplain management and biodiversity}

According to our assessments, biodiversity decreased significantly due to conventional river regulations during the last two centuries, but has been positively affected by recent restoration efforts in the investigated countries. The main pressure for floodplain biodiversity is still the alteration of hydrological conditions, but also alien species, agriculture and forestry, water pollution and eutrophication, settlements and industrial infrastructure, soil pollution, and hydropower have important impacts across the six investigated countries. Biodiversity may benefit from multifunctional management, but evidence is rare as only few projects have documented the respective impacts and responses. Supported by the situation in Ireland, Germany, Hungary, and the Ukraine, the general impression is that a systematic scientific evaluation of the impacts of multifunctional floodplain management is lacking much too often. MFM projects with particular focus on the conservation of biodiversity should imply comprehensive evaluations of biodiversity impacts at habitat and species level (Jähnig et al. 2010). Restoration measures addressing relatively short river sections mainly improve habitat diversity of rivers and floodplains, but are often 
Table 4 Floodplains, floodplain management approaches, and evidence for biodiversity impact in the six investigated European countries

\section{Country Status}

\section{Biophysical conditions}

IE Many small river systems throughout the country; a number of large rivers with extensive floodplains

NL "The Dutch live in a river delta"

DE All kinds of rivers and floodplains from alpine to lowland, from pristine streams to heavily modified waterbodies but mainly dominated by large river systems with formerly extensive floodplains

SK Dense network of streams including mountain brooks, upland small rivers and mighty rivers in lowlands; average density of river network is $1.1 \mathrm{~km} / \mathrm{km}^{2}$

HU Meandering rivers in a flat landscape

UA Most rivers are regulated and transformed into reservoir systems

Main land uses in floodplains

IE Hydropower, agriculture, housing, tourism and leisure

NL Most land is farmland, secondary functions are nature conservation and recreation

DE Agriculture, forestry, settlements and industry

SK Hydropower, settlements, agriculture and industry, nature protection, recreation and tourism

HU Agriculture, forestry, nature conservation

UA Hydropower, agriculture, settlements and industry, recreation, quasi-natural remnants

Governance level responsible for floodplain management

IE Combination of central (e.g. hydropower) and local/regional (e.g. agriculture, housing)

NL Centralized, decisions are taken at national and regional levels. However land users do influence local (micro-level) development

DE Federal State and regional responsibility

SK Case dependent, mostly local, but for large rivers regional to governmental

HU Centralized, but involvement of regional and local stakeholders

UA Central and regional, but not lower than province level

Main strategic approaches/management aims

IE Emphasis is currently on flood alleviation and drainage; some priority given to facilitation of fish movement

NL Flood protection is top priority, and overriding other sectors with regard to planning and land use. The Ministry for Water and Infrastructure has a key role in the floodplain areas.

DE Navigation along large rivers most important, flood protection also high priority, recently (mainly local or regional) efforts to combine the two with floodplain restoration and biodiversity

SK Decrease of water pollution, nature conservation (incl. 12 Ramsar sites), flood protection, revitalization

HU Flood protection is the top priority, beside this: forestry, nature conservation, navigation

UA Developed legislation of river conservation, but weak legal enforcement

Multifunctional management approaches

IE Weir construction that allows both water flow control and passage of aquatic species; provision of habitat for species of conservation concern; engagement with key stakeholders, e.g. fisheries, farmers and local communities

NL Management is multifunctional, with particular interest for flood protection, nature conservation and tourism. However, flood protection is overriding all other interests 
Table 4 continued

\begin{tabular}{|c|c|}
\hline Country & Status \\
\hline $\mathrm{DE}$ & $\begin{array}{l}\text { Some efforts to restrict and extensify agricultural use, nationwide program for restoring } \\
\text { hydrological connectivity on big navigable rivers, local and regional but still limited activities } \\
\text { for dyke relocation, restoration and biodiversity conservation to foster synergies and win-wins } \\
\text { between the different uses }\end{array}$ \\
\hline SK & $\begin{array}{l}\text { Danube and Váh-creation of multimodal transport corridors respecting nature values and } \\
\text { offering possibilities for tourism }\end{array}$ \\
\hline $\mathrm{HU}$ & $\begin{array}{l}\text { Multifunctional projects dealing with reintroduction of grazing, fighting against invasive species } \\
\text { and hydrological rehabilitation }\end{array}$ \\
\hline UA & Drainage or irrigation are primary aims, biodiversity conservation may be concomitant \\
\hline \multicolumn{2}{|c|}{ Evidence for biodiversity impact of MFM } \\
\hline IE & Currently no evidence for biodiversity impacts of MFM projects available \\
\hline NL & $\begin{array}{l}\text { Many projects are still in the implementation phase, but some projects have been ongoing for } \\
20 \text { years and show positive impacts regarding biodiversity, in particular due to increased } \\
\text { natural dynamics and increased habitat diversity. As a result, rare and protected species have } \\
\text { returned. }\end{array}$ \\
\hline $\mathrm{DE}$ & $\begin{array}{l}\text { Still few studies and lack of effective monitoring but a tendency towards positive impacts upon } \\
\text { species as well as habitats }\end{array}$ \\
\hline SK & $\begin{array}{l}\text { Rich evidence mainly from Gabčíkovo and the Váh cascade including whole spectrum of both } \\
\text { aquatic and terrestrial groups of taxa }\end{array}$ \\
\hline HU & Week evidence, but seemingly bird, fish and plant diversity increased \\
\hline UA & Restoration of natural hydrological regimen resulted in biodiversity increase \\
\hline
\end{tabular}

$I E$ Ireland, $N L$ the Netherlands, $D E$ Germany, $S K$ Slovakia, $H U$ Hungary, $U A$ Ukraine

insufficient for changes in benthic invertebrate communities (Jähnig et al. 2010). It has been shown that plant diversity is crucial for ecosystem service supply (Isbell et al. 2011) and that biodiversity-rich natural or semi-natural floodplain habitats provide more ecosystem services than cultivated land use types (Felipe-Lucia and Comín 2015). As a consequence, biodiversity conservation must be a primary focus of sustainable MFM approaches. In Slovakia, for instance, the biodiversity effects of MFM are positive in protected floodplains with restricted management or management anchored in legislative acts. Here evidence of biodiversity effects is rather well documented and the creation and restoration of wet grasslands has become increasingly important following alarming biotope declines in many countries (José et al. 1999; Machar 2008). However, for small rivers and brooks outside protected areas that are managed within the local municipalities, decisions often fail to consider biodiversity, leading to high levels of pollution. For large rivers, particularly the Danube, Morava and Váh, conflicts among stakeholders in favour of hydropower production and dyke construction versus nature conservation are still ongoing. In the investigated countries, there is particularly little evidence for biodiversity effects concerning the large number of mostly smaller projects. Effects of MFM projects should be assessed by evaluating temporal change in biodiversity but also in supply (and demand) of all relevant ecosystem services (Felipe-Lucia and Comín 2015). When lacking quantitative data, expert knowledge can provide an alternative for such assessments (cf. Schindler et al. 2014). However, lack of thorough evaluation does not equal lack of important positive impacts. For many MFM projects, knowledge gaps must be interpreted as meaning that no evidence of an impact was assessed or found, rather than as providing evidence of no impact. 


\section{Outlook}

Despite some of the challenges outlined above, there is a window of opportunity to push forward the establishment of multifunctional floodplains due to the public attention generated by multiple, devastating floods in Europe in the last decade, which showed the failure of monofunctional approaches, and by the enhanced interest and take up of the concepts of ecosystem services and multifunctionality by recent policies (e.g. policies to support "Green Infrastructure" across Europe; EC 2011; EEA 2015). The identification of suitable means how the interests of water and wetlands can be mainstreamed into decision making is supported by the "TEEB For Water and Wetlands" launched in February 2013. MFM is clearly linked furthermore to the ideas of Ecosystem based Adaptation (building resilient ecosystems for better adaptation to flood risk or other consequences of climate change; EEA 2015) and also to the targets of the Green Economy. On a national level, processes linked to e.g. "TEEB For Water and Wetlands", the Mapping and Assessment of Ecosystems and their Services in Europe (MAES) which is one of the key actions of the EU Biodiversity Strategy to 2020, Green Economy initiative, and Ecosystem based Adaptation to the impacts of climate change are often managed in parallel and the opportunity for synergies is seldom fully exploited. Synergies need to be explored and potential alliances of stakeholders actively supported.

\section{Insights for 'BiodiversityKnowledge'}

In the frame of the trial assessment 'conservation case' dealing with 'Impact of multifunctional floodplain management on biodiversity and ecosystem services' three assessments were conducted varying in rigour and level of formalization of the evidence synthesis approach (Schindler et al. 2016). The present expert consultation was the assessment with the lowest level of formalization. It gained strong momentum by the particularly high commitment of experts who were highly motivated to provide their national expertise for an assessment at European scale. It was also outstanding that due to the experts' commitment, we easily integrated knowledge gathered in grey literature and non-English journals. Challenges faced included that during initial stages the homogeneity of national texts was not sufficient either in terms of content or of language (see Schindler et al. 2013b). Thus only rather generic interpretations, conclusions and recommendations could be derived in this assessment. At the intermediate level of formalization, Schindler et al. (2014) developed an expert consultation to define and apply a landscape-based multifunctionality index. This index assesses the effects of nine bundles of management interventions on 21 ecosystem services provided by European floodplains. The study delivered a novel and innovative product and was rather cost effective, driven by a high level of engagement of experts. Rigorous methodologies such as systematic reviews ensure reliable knowledge syntheses that are less susceptible to bias. However, European-wide systematic reviews could only be framed and initiated in the frame of the 'BiodiversityKnowledge'-trial assessments (Araújo et al. 2013; Schindler et al. 2013a, b), but had to be finalized with additional resources afterwards (Bertocci et al. 2015). Despite significant interest at the beginning, efficient implementation of the systematic review on biodiversity impacts of floodplain management was hindered by the experts' lack of familiarity with the approach and the need for an intensive and time consuming examination of the methodological demands (CEE 2013) and the specific settings developed for the particular systematic review on effects of floodplain management (Schindler et al. 2013a). 


\section{Conclusions}

In summary, MFM has become an issue of growing attention in several European countries; however, implementation is partly still in its infancy and varies widely in Europe. Multifunctional approaches for managing floodplain landscapes are seemingly rather successful, particularly where integration of all existing uses and demands are carefully considered. Win-win situations need to be achieved (Schindler et al. 2014) and biodiversity has to play a crucial role (Felipe-Lucia and Comín 2015). The impacts of the implemented measures on biodiversity and the provision of ecosystem services are largely undocumented and under-researched. The scarcity of multifunctional approaches is also reflected by the lack of large-scale vision in the management and use of rivers and floodplains beyond county, federal or national boundaries, integrating all disciplines and stakeholders over extended areas, such as the floodplains of a whole catchment or at least significant functional parts of it. Since there is hardly an institution with responsibility for such areas, the resulting lack might not be too surprising. In order to make full use of synergies and for the establishment of sustainable and efficient solutions, this should be addressed. Entirely new initiatives would probably be needed to bridge institutional, administrative and other boundaries and to achieve far-reaching cross-compliance. Expert consultations with low level of formalization can be of advantage, because high level of expert engagement might be reached. However, they might suffer from low possibilities for interpretation of results and deriving novel conclusions and recommendations.

Acknowledgments Open access funding provided by University of Vienna. This study was partly funded by the European Commission under FP7 as coordination action "biodiversity.knowledge" (Acronym KNEU, Grant No. 265299).

Open Access This article is distributed under the terms of the Creative Commons Attribution 4.0 International License (http://creativecommons.org/licenses/by/4.0/), which permits unrestricted use, distribution, and reproduction in any medium, provided you give appropriate credit to the original author(s) and the source, provide a link to the Creative Commons license, and indicate if changes were made.

\section{References}

Agricola HJ, Doorn AMV, Os JV (2011) Parels voor de zwijnen? Effecten van landbouwontwikkelingen op het landschap. Bodem 2:8-10

Akinfiev IJ (1889) Vegetation of Yekaterinoslav at the end of the first century of its existence. Yekaterinoslav

Andrásfalvy B (2007) A Duna mente népének ártéri gazdálkodása (Historical floodplain management along the Danube, Hungary). Ekvilibrum Kiadó, Budapest

Anonymous (2003) Shannon River Basin Management Project: Current management of water levels, River Shannon. Shannon River Basin District. http://www.shannonrbd.com/pdf/currentmgtwaterlevelsreport. pdf. Accessed 18 Apr 2016

Anonymous (2004). Hydropower engineering and the environment. Libra, Kyiv

Anonymous (2012). National report on the implementation of the Ramsar Convention on wetlands. http:// eng.menr.gov.ua/docs/activity-international3/National\%20Report\%20of\%20Ukraine\%20to\%20Ransar\% 20Convention-2011_01022012.doc. Accessed 18 Apr 2016

Araújo RM, Bartsch I, Bekkby T, Erzini K, Sousa-Pinto I (2013) What is the impact of kelp forest density and/or area on fisheries? Systematic review protocol. Environ Evid 2:15. doi:10.1186/2047-2382-2-15

Armbruster J, Muley-Fritze A, Pfarr U et al (ed) (2006) FOWARA - Forested Water Retention Areas. Guideline for decision makers, forest managers and land owners. http://www.landespflege-freiburg.de/ ressourcen/fowara_guideline.pdf. Accessed 12 Nov 2015 
Avakjan AB, Sharapov VA (1968) Water reservoirs of hydroelectric power stations of the USSR. Energiia, Moscow

Balázs B, Bodorkós B, Bela G, Podmaniczky L, Balázs K (2009) Multifunctional farming and survival strategies in the borsodi floodplain. In: Piorr A, Müller K (eds) Rural landscapes and agricultural policies in Europe. Springer, Berlin, pp 284-305

Banik MV, Korshunov AV (2014) Terrestrial vertebrates of Ukrainian part of Siversky Donets river basin: current state, trends of changes in numbers, and protection problems. J Karazin Khark Nat Univ Ser Biol 20:91-103

Baranovsky BA (2000) Vegetation of the in-channel basin. Dnipropetrovsk University Press, Dnipropetrovsk

Baranovsky BA (2005) Biodiversity of riverside flora of the former rapids Dnieper and necessity of conservation of rare and endangered species. In: Proceedings of the international scientific-practical conference problems of conservation, rehabilitation and enrichment of biodiversity in conditions of the anthropogenically changed environment. Prospectus, Dnipropetrovsk, pp 71-73

Baranovsky, BO, Kuznetsova OV, Krutenko VV (2009c) Use of cereals for meadow formation of banks slopes. In: Proceedings of the international scientific-practical conference on «International Water Day». Kremenchuk, p 39

Baranovsky BA, Aleksandrova AA (2005) Phytodiversity of the basic ecotopes of the Samara river floodplain. Ecol Noospherol 16:135-144

Baranovsky BA, Demianov VV, Gryniuk VI (2001) Modern state of small rivers of the steppe zone of Ukraine. Abstr. Int. Conf. "Ecology of crisis regions of Ukraine”. DNU Press, Dnipropetrovsk, p 109

Baranovsky BA, Zagubizhenko NI, Mikolaichuk TV (2007) Biodiversity of hydrobionts of the anthropogenically transformed reservoirs of the Samara floodplains. Questions of steppe silvics and forest rehabilitation of lands. Dnipropetrovsk University Press, Dnipropetrovsk, pp 30-43

Baranovsky BO, Ivanko IA, Zhdanova TS (2009a) Features of shady influence of artificial water-protective plantations as a biological method of water bodies treatment. In: Proceedings of the international scientific-practical conference on «International Water Day ». Kremenchuk, p 45

Baranovsky BO, Kulik AF, Novosel IO, Chorna EJ (2009b) Creation of riverside belts on restorated beds of steppe rivers. In: Proceedings of the international scientific-practical conference on « International Water Day ». Kremenchuk, p 41

Baranovsky B, Gasso V, Schindler S (2013) Multifunctional management and biodiversity conservation of Ukrainian floodplain landscapes. Visnyk of Kharkiv National Agrarian University 5:184-188

Bártol R (2008) Újjáéledő Tisza-ártér. A Kiskunsági Nemzeti Park Igazgatóság KIOP projektjei. Kiskunsági Nemzeti Park Igazgatóság, Kecskemét. http://www.kontyvirag.hu/adat/tartalom/elohelyrekonstrukc io/\%C3\%891\%C5\%91helyrekonstrukci\%C3\%B3-kiadv\%C3\%A1ny.pdf. Accessed 21 Dec 2015

Beckmann A, Jen S (2004) Natura 2000 in the New EU Member States. Status report and list of sites for selected habitats and species. WWF EU Accession Initiative

Belgard AL (1950) Forest vegetation of Southeast USSR. Kiev University, Kiev

Benedict MA, McMahon ET (2002) Green infrastructure: smart conservation for the 21st century. Renew Resour J 20:12-17

BfN (Bundesamt für Naturschutz) (2013) Erfassung überregional bedeutsamer Projekte zur Auenrenaturierung und zur Wiederherstellung von Überschwemmungsflächen-bundesweite Übersicht. Unpublished Study, BFN

Biró M (2009) Floodplain hay meadows along the river Tisza in Hungary. In: Veen P, Jefferson R, Smidth J, Straaten J (eds) Grasslands in Europe of high nature value. KNNV Publishing, Zeist, pp 238-245

BMU (Bundesministerium für Umwelt, Naturschutz und Reaktorsicherheit) (2008) Symposium Biodiversity of surface waters, floodplains and groundwater. October 29/30 2008, Bonn, Germany. Federal Ministry for the Environment, Nature Conservation and Nuclear Safety (BMU), Berlin

BMU (Bundesministerium für Umwelt, Naturschutz und Reaktorsicherheit), BfN (Bundesamt für Naturschutz) (2009) Auenzustandsbericht. Flussauen in Deutschland, Berlin. http://www.bfn.de/0324_ auenzustandsbericht.html. Accessed 12 Nov 2015

Bódis E, Borza P, Potyó I, Puky M, Weiperth A, Guti G (2012) Invasive mollusk, crustacean, fish and reptile species along the Hungarian stretch of the river Danube and some connected waters. Act Zool Acad Sci Hun 58(Suppl):29-45

Borsos B, Flachner Zs, Nagy G, Fehér L, Balogh P (2010) A practical guide to integrated land management methods intended to improve land use and water management efficiency in the Tisza basin. Report of ICPDR/UNDP/GEF project. https://docs.google.com/file/d/0B_HNgprzQP0aMDlmMzIyZGYtNzIxNy 00YzYyLTgxZmMtMzdmOTNhYmZmMzZk/edit?hl=en\&pli=1. Accessed 12 Nov 2015

Botta-Dukát Z (2008) Invasion of alien species to Hungarian (semi-) natural habitats. Act Bot Hun 50(Suppl):219-227 
Browne A, Dunne F, Roche N (2002) A preliminary study of the Upper Shannon floodplain. Report for Dúchas the Heritage Service, Department of Arts, Heritage, Gaeltacht and the Islands, Dublin, Ireland

BROZ (2003) Conservation and management of Danube floodplain forests. Broz, Bratislava

Brunotte E, Dister E, Günther-Diringer D, Koenzen U, Mehl D (2009) Flussauen in Deutschland-Erfassung und Bewertung des Auenzustandes. Naturschutz Biol Vielfalt 87:1-244

Bulakhov VL, Gasso VY, Pakhomov OY (2007) Biodiversity of Ukraine. Dnipropetrovsk province. Amphibians and Reptiles (Amphibia et Reptilia). Dnipropetrovsk University Press, Dnipropetrovsk

Bulakhov VL, Gubkin AA, Ponomarenko OL (2008) Biodiversity of Ukraine. Dnipropetrovsk province. Non-Perching Birds (Aves. Non-Passeriformes). Dnipropetrovsk University Press, Dnipropetrovsk

Bulánková E (1995) Dragonflies (Odonata) and aquatic bugs (Heteroptera aquatica) of stagnant waters in the region of the Gabčíkovo project. In: Mucha I (ed) Gabčíkovo part of the Hydroelectric power project environmental impacts review. Faculty of Natural Sciences, Commenius University, Bratislava, pp 297-300

Byrne C, Fanning A (2015) Water quality in Ireland 2010-2012. Environmental Protection Agency, Wexford

Campbell E, Foy B (2008) Executive summary of Lough Melvin Catchment Management Plan. Northern Regional Fisheries Board, Tipperary

Čimborová A, Bartková E (2014) Pilot testing of Water Framework Directive in Eastern Slovakian Lowlands. CEEWEB. http://www.ceeweb.org/wp-content/uploads/2014/10/2_Slovakia_-in-Laborec_-inte grating-WFD-and-Natura-2000.pdf. Accessed 26 Apr 2016

Creemers RCM (1994) Amfibieën in uiterwaarden (Amphibian species in floodplains). Voortplantingsplaatsen van amfibieën in uiterwaarden. Catholic University Nijmegen/Ministry of Agriculture, The Hague

CRUE Funding Initiative on Flood Risk Management Research (ed) (2008) Flood risk reduction by PReserving and restOring river Floodplains (PRO_Floodplain). CRUE Res Report I-3:1-151. www.crueeranet.net/Calls/Final_Report_PRO_Floodplain.pdf. Accessed 12 Nov 2015

De Mulder EFJ, Geluk MC, Ritsema IL, Westerhoff WE, Wong TE (2003) De ondergrond van Nederland. Wolters-Noordhoff, Groinngen

DECLG ([Irish] Department of Environment, Community and Local Government) (2013). http://www. environ.ie/en/Environment/Water/WaterQuality/WaterFrameworkDirective/. Accessed 12 Nov 2015

Demény F, Keresztessy K (2007) A nagykörűi Anyita-tó 2006. évi lehalászásának halfaunisztikai és tájgazdálkodási értékelése (Fishfaunistic and landscape-farming estimate of the fishing of Anyita-lake in Nagykörü in 2006). Pisces Hung 2:135-139

Denisova AI, Timchenko VM, Nakhshina EP et al (1981) Hydrology and hydrochemistry of Dnieper and its water basins. Naukova dumka, Kyiv

Dister E (1992) Ökologischer Forderungen an den Hochwasserschutz. Wasserwirtschaft 82(7/8):372-375

Dister E (1999) Evaluation of wetlands and floodplain areas in the Danube river basin. Final report in the frame of Developing the Danube River Basin pollution Reduction Programme, UNDP/GEF Project, New York

Dister E, Gromer D, Obrdlik P, Peterman P, Schneider E (1990) Water management and ecological perspectives of the Upper Rhine's floodplains. Regul Rivers Res Manag 5:1-15

Dromey M, O'Keeffe C (2004) Designation of sites for fish under the EU Habitats Directive. Biol Environ 104B:103-105

EC (European Commission) (2005) Communication from the Commission to the Council and the European Parliament. Draft declaration on guiding principles for sustainable development, COM 218 final (2005), Brussels

EC (European Commission), (2007) Directive 2007/60/EC of the European Parliament and of the Council of 23 October 2007 on the assessment and management of flood risk. Official Journal of European Communities 2007(L288):27-34

EC (European Commission) (2011) Our life insurance, our natural capital: an EU biodiversity strategy to 2020, COM 244 (2011), Brussels

Ecsedi Z (ed) (2004) A Hortobágy madárvilága (Birds of the Hortobágy). Hortobágyi Természetvédelmi Egyesület-Winter Fair, Balmazújváros-Szeged

EEA (European Environment Agency) (2007). Halting the loss of biodiversity by 2010: proposal for a first set of indicators to monitor progress in Europe. EEA Technical Report no. 11/2007. European Environment Agency, Copenhagen

EEA (European Environment Agency) (2015) Exploring nature-based solutions: The role of green infrastructure in mitigating the impacts of weather- and climate change-related natural hazards. EEA Technical report No 12/2015. European Environment Agency, Copenhagen. http://www.eea.europa.eu/ publications/exploring-nature-based-solutions-2014. Accessed 15 Nov 2015 
Elek B, László K, Pintér B, Vojtek É (2013) Az Ős-Dráva program keretei között megvalósuló “Szövétnek I." projekthez tartozó Kelet-Ormánsági települések természetföldrajzi jellegzetességeinek bemutatása (Presentation of the natural characteristics of villages situated in East-Ormánság area in Hungary, included in „Torchlight I.” project of „Original Dráva Program”) Humán Innovációs Szemle IV(12): $65-75$

Erös T (2007) Partitioning the diversity of riverine fish: the roles of habitat types and non-native species. Freshw Biol 52:1400-1415

ESB (2015) Official website of the Electricity Supply Board. www.esb.ie. Accessed 21 Dec 2015

Felipe-Lucia MR, Comín FA (2015) Ecosystem services-biodiversity relationships depend on land use type in floodplain agroecosystems. Land Use Policy 46:201-210

Fliervoet JM, Van den Born RJG, Smits AJM, Knippenberg L (2013) Combining safety and nature: a multistakeholder perspective on integrated floodplain management. J Environ Manag 128:1033-1042

Förster S (2008): An analysis of hydraulic, environmental and economic impacts of flood polder management at the Elbe River. http://opus.kobv.de/ubp/volltexte/2008/2726/. Accessed 12 Nov 2015

Funk A, Reckendorfer W, Kucera-Hirzinger V, Raab R, Schiemer F (2009) Aquatic diversity in a former floodplain: remediation in an urban context. Ecol Engineer 35(10):1476-1484

Gasso V (2009) Biogeocenotic features of the reptiles distribution in the central steppe Pridneprovye environment. Ecol Noospherol 20:102-109

Geilen N, Jochems H, Krebs L et al (2004) Integration of ecological aspects in flood protection strategies: defining an ecological minimum. River Res Appl 20:269-283

Gerasimova OV (2006) Flora of algae of the water basins of Dniprovsko-Orelsky nature reserve. Synopsis of dissertation. Kyiv

Giller PS, Johnson M, O'Halloran J (2002) Managing the impacts of forest clearfelling on stream environments. COFORD, Dublin

Grossmann M, Hartje V, Meyerhoff J (2010) Ökonomische Bewertung naturverträglicher Hochwasservorsorge an der Elbe. Naturschutz Biol Vielfalt 89, Bundesamt für Naturschutz, Bonn

Grytsan YI (2000) Ecological basics of transformational influence of forest vegetation on the steppe environment. Dnipropetrovsk University Press, Dnipropetrovsk

Grytsan YI, Baranovsky BO, Kostiukov TO, Rud VV (2006) Ecology-social aspects of forest ecosystems functioning of the "Diovska dacha" hole. V Int. Sci.-Pract. Conf. Problems of Ecology and Ecological Education. Kryvyi Rig

Gusieva N (2012) Water resources of Ukraine and their accounting. Seminar for Eastern Europe, South Caucasus and Central Asia countries (EECCA) on water statistics, Almaty. http://www.water.eurostateecca-seminars.com/index.php?option=com_docman\&task=doc_download\&gid=155\&Itemid=\&lang= en. Accessed 12 Nov 2015

Haraszthy L (ed) (2014) Natura 2000 fajok és élőhelyek Magyarországon. Pro Vértes Közalapítvány, Csákvár

Hein T, Schwarz U, Habersack H, Nichersu I, Preiner S, Willby N, Weigelhofer G (2016) Current status and restoration options for floodplains along the Danube River. Sci Total Environ 543:778-790

Holubová K (2000) Some aspects of the bedload transport regime in the Slovak section of the Danube River. In: Proceedings of 20th conference of the Danubian countries on hydrological forecasting and hydrological bases of water management, Bratislava, 4-8 September 2000. Institute of Hydrology SAS, Bratislava

Holubová K, Steiner F (2011) Joint efforts for cross-border restoration of the Morava river Primary restoration actions derived from the project. In: DANUBEPARKS international workshop-river morphology and restoration, 26-27 May, 2011. Orth an der Donau

Holubová K, Hey RD, Lisický MJ (2005) Middle Danube tributaries: constraints and opportunities in lowland river restoration. Arch Hydrobiol Suppl Large Rivers 15(1-4):507-519

Huba M, Trubíniová L, Simončičová K (1998) Biodiversity in Slovakia from the NGO perspective. SEPS

Hutton SA, Harrison SSC, O'Halloran J (2008) Forests and surface water eutrophication and sedimentation. Western River Basin District. http://www.wfdireland.ie/docs/22_ForestAndWater/Forest\%20and\% 20Water_UCC_Draft\%20Final\%20Report.pdf. Accessed 21 Dec 2015

ICPDR (2011) Integrated Tisza River Basin Management Plan. ICPDR, IKSD

Irish Water (2015a) Water Supply Project, Eastern and Midlands Region: Project Need Report. Irish Water. http:// www.watersupplyproject.ie/wp-content/uploads/2015/03/Vol-1_Irish-Water-Needs-Report.pdf. Accessed 21 Dec 2015

Irish Water (2015b). http://www.watersupplyproject.ie/emerging-preferred-option-identified-on-major-newwater-source-for-the-east-and-midlands-regions/. Accessed 21 Dec 2015

Isbell F, Calcagno V, Hector A, Connolly J, Harpole WS et al (2011) High plant diversity is needed to maintain ecosystem services. Nature 477(7363):199-202 
Jähnig SC, Brabec K, Buffagni A, Erb S, Lorenz AW et al (2010) A comparative analysis of restoration measures and their effects on hydromorphology and benthic invertebrates in 26 central and southern European rivers. J Appl Ecol 47:671-680

Jongmans AG, Berg MW, Sonneveld MPW, Peek G, Saparoea RM (2013) Landscapes of the Netherlands geology, soil and land use. Wageningen Academic Publishers, Wageningen

José PJ, Joyce PV, Wade PM (1999) European Wet Grassland. Guidelines for management and restoration. RSPB, Sandy Lodge

Kabat P, Fresco LO, Stive MJF, Veerman CP, van Alphen JSLJ, Parmet BWAH (2009) Dutch coasts in transition. Nat Geosci 2(7):450-452

Kail J, Brabec K, Poppe M, Januschke K (2015) The effect of river restoration on fish, macroinvertebrates and aquatic macrophytes: a meta-analysis. Ecol Indic 58:311-321

King JL, Marnell F, Kingston N et al (2011) Ireland Red List No. 5: Amphibians, Reptiles \& Freshwater Fish. National Parks and Wildlife Service, Department of Arts, Heritage and the Gaeltacht, Dublin

Klinda J, Lieskovská Z (1998) State of the environment report of the Slovak Republic 1998. Ministry of Environment of Slovak Republic, Bratislava

Klinda J, Lieskovská Z (2010) State of the environment report of the Slovak Republic 2010. Ministry of Environment of Slovak Republic, Bratislava

Kochet VM (2010) Modern state of ichthyofauna of small rivers of the Dnipropetrovsk region. Sci Proc. Ternopil National Pedagogical University. Biology Series 2(43):280-83

Koenzen U (2005) Fluss- und Stromauen in Deutschland. Typologie und Leitbilder. Ergebnisse des F + EVorhabens "Typologie und Leitbildentwicklung für Flussauen in der Bundesrepublik Deutschland" des Bundesamtes für Naturschutz. FKZ 80382 100. SR Angewandte Landschaftsökologie 65:1-327

Koreliakova IL (1977) Vegetation of the Kremenchug water reservoir. Naukova dumka, Kyiv

Krno I, Šporka F, Matis D et al (1999) Development of zoobenthos in the Slovak Danube inundation area after the Gabčíkovo hydropower structures began operating. In: Gabčíkovo part of the Hydroelectric Power Projekt-Environmential impact review. Comenius University Bratislava, pp 175-00

Klimo E, Hager H, Matič S, Anič I, Kulhavý, J (2008) Floodplain forests of the Temperate Zone of Europe, Lesnická Práce, Kostelec nad Černými lesy

Kulik AF, Baranovsky BO, Vasyliuk OM (2008) Rehabilitation and conservation of biogeocenoses of small rivers of Prydniprové. Lviv, pp 225-226

Kurstjens G, Peters B (2011) 15 jaar ecologisch herstel langs de Maas: hoe reageert de flora? De Levende Natuur 112:11

Kurstjens G, Peters B (2012a) Rijn in beeld, deel 1: Ecologische resultaten van 20 jaar rivierontwikkeling langs de Rijntakken. Projectgroep Rijn in Beeld, Berg en Dal/Beek-Ubbergen

Kurstjens G, Peters B (2012b) Rijn in beeld, deel 2: Inrichting, beheer en beleid langs de grote rivieren., Projectgroep Rijn in Beeld, Berg en Dal/Beek-Ubbergen

Lájer K (2012) Comparison of different grassland management methods on the Danube floodplain, Kölked and Drávaszentes. Duna-Dráva National Park Directorate, Pécs

Leyer I (2005) Predicting plant species' responses to river regulation: the role of water level fluctuations. J Appl Ecol 42(2):239-250

Lisický MJ, Mucha I (eds) (2003) Optimalizácia vodného režimu ramennej sústavy v úseku Dunaja Dobrohošt'-Sap z hl'adiska prírodného prostredia. PRIF UK, Splnomocnenec vlády SR pre výstavbu a prevádzku sústavy VD G-N, Konzultačná skupina Podzemná Voda, s.r.o., Bratislava

Lorenz AW, Korte T, Sundermann A, Januschke K, Haase P (2012) Macrophytes respond to reach-scale river restorations. J Appl Ecol 49:202-212

Loza I, Nazarenko N, Baranovsky B (2004) A Forecast of Changes in the Foreshore Ecosystem of River South Bug as a Result of Enlargement of the Alexandrovskoye Water Basin. In: Proceedings of the NATO advanced research workshop "Flood risk management-hazards, vulnerability, mitigation measures", Ostrov u Tise, pp 107-122

Lüderitz V, Speierl T, Langheinrich U, Völkl W, Gersberg RM (2011) Restoration of the upper Main and Rodach rivers - the success and its measurement. Ecol Engineer 37:2044-2055

Machar I (2008) Floodplain forests of Litovelské Pomoraví and their management. J For Sci 54:355-369

Maher CA (2013) The Shannon Callow Flood Meadows: an investigation of how plant and dipteran communities are influenced by hydrological variables and farming practices. Dissertation, NUI Galway, Ireland

Maher CA, Sheehy Skeffington MJ, Gormally MJ (2011) Hay meadow plant communities on the Shannon Callows: responses to summer flooding and changes in management. In Ó hUallacháin D, Finn J (eds) Teagasc biodiversity conference proceedings. conserving farmland biodiversity: lessons learned and future prospects. Teagasc, Carlow, pp 72-73 
MA-Millennium Ecosystem Assessment (2005) Ecosystems and Human Well-being: Synthesis. Island Press, Washington, DC

Margóczi K, Roboz Á (2011) Landscape changes in the Tiszaalpár floodplain. Conference VII, Abstracts. MTBK, Hungary, p 138

Martin JR (1998) A species-based approach to the conservation of Ireland's threatened vascular plant species, using complementary in situ and ex situ methodologies. Dissertation, Trinity College Dublin

Mauerhofer V (2010) Missing links: how individuals can contribute to reserve policy enforcement on the example of the European Union. Biodivers Conserv 19:601-618

Mihók B, Zs Erös-Honti, Gálhidy L, Gy Bela, Illyés E, Tinya F (2006) The status of the South-Borsod Floodplain from the viewpoint of local people and ecologists. An interdisciplinary research on traditional ecological knowledge. Természetvédelmi Közlemények 12:79-103

Mitchell F (1990) Shell guide to reading the Irish landscape. Country House, Dublin

Molnár ZS, Borhidi A (2003) Continental alkali vegetation in Hungary. syntaxonomy, landscape history, vegetation dynamics, and conservation. Phytocoenologia 21:235-245

Molnár ZS, Biró M, Bölöni J, Horváth F (2008a) Distribution of the (semi-)natural habitats in Hungary I. Marshes and grasslands. Act Bot Hung 50(Suppl):59-105

Molnár ZS, Bölöni J, Horváth F (2008b) Threatening factors encountered: actual endangerment of the Hungarian (semi-) natural habitats. Act Bot Hung 50(Suppl):199-217

Moorkens EA (2000) Conservation management of the Freshwater Pearl Mussel Margaritifera margaritifera. Part 2: Water quality requirements. Irish Wildlife Manuals, No. 9. National Parks and Wildlife Service, Department of Arts, Heritage and the Gaeltacht, Dublin

Mucha I (ed) (1999) Gabčíkovo part of the hydroelectric power project-environmental impact review. Comenius University, Bratislava

Müller U (2010) Hochwasserrisikomanagement: Theorie und Praxis. Vieweg+Teubner, Wiesbaden

Mykolaichuk TV (2006) Zooplankton of different biotopes of Zaporizke water reservoir. Visnyk Dnipropetrovsk Univ Biol Ecol 14:107-113

Nesshöver C, Vandewalle M, Wittmer H, Balian EV, Carmen E et al (2016) The network of knowledge approach: improving the science and society dialogue on biodiversity and ecosystem services in Europe. Biodivers Conserv. doi:10.1007/s10531-016-1127-5

Nielsen HO, Frederiksen P, Saarikoski H, Rytkonen AM, Pedersen AB (2013) 'How different institutional arrangements promote integrated river basin management. Evidence from the Baltic Sea Region. Land Use Pol 30:437-445

Nijland HJ, Cals MJR (eds) (2001) River restoration in Europe: practical approaches. Proceedings of the Conference. RIZA report $\mathrm{nr}$ 2001.023, Wageningen

Nikolaenko VG (1980) Forest and protection of reservoirs against pollution. Lesnaia promyshlennost, Moscow

Nilsson C, Reidy CA, Dynesius M, Revenga C (2005) Fragmentation and flow regulation of the world's large river systems. Science 308:405-408

O'Grady MF (2006) Channels and Challenges. Enhancing Salmonid Rivers. Irish Freshwater Fisheries Ecology \& Management Series 4. Central Fisheries Board, Dublin

O’Neill FH, Perrin PM, Barron SJ (2008) Ballyseedy Wood: a 50-year management plan. Unpublished report submitted to Kerry County Council, Ireland

Oszlányi J (1999) Consequences of anthropic impact on Danube floodplain forests in Slovakia. Ekológia (Bratislava) 18(Suppl 1):103-110

Paavola J, Gouldson A, Kluvánková-Oravská T (2009) Interplay of actors, scales, frameworks and regimes in the governance of biodiversity. Environ Policy Govern 19:148-158

Pišút P (2002) Channel evolution of the pre-channelized Danube River in Bratislava, Slovkia (1712-1886). Earth Surf Proces Landforms 27:369-390

Pišút P (2006) Changes in the Danube riverbed from Bratislava to Komárno in the period prior to its regulation for medium water (1886-1896). In: Mucha I, Lisický MJ (eds) Slovak-Hungarian environmental monitoring on the Danube. Groundwater Consulting, Bratislava, pp 180-186

Plieninger T, Bieling C, Fagerholm N, Byg A, Hartel T et al (2015) The role of cultural ecosystem services in landscape management and planning. Curr Opin Environ Sustain 14:28-33

Poff NL, Allan JD, Bain MB et al (1997) The natural flow regime. a paradigm for river conservation and restoration. Bioscience 4:769-784

Pottgießer T, Sommerhäuser M (2008) Beschreibung und Bewertung der deutschen FließgewässertypenSteckbriefe und Anhang

Rauschmayer F, van den Hove S, Koetz T (2009) Participation in EU biodiversity governance: how far beyond rhetoric? Environ Plan C 27:42-58 
Rijke J, van Herk S, Zevenbergen C, Ashley R (2012) Room for the River: delivering integrated river basin management in the Netherlands. Int J River Basin Manag 10(4):369-382

Rinaldi M, Wyżga B, Dufour S, Bertoldi W, Gurnell A (2013) River processes and implications for fluvial ecogeomorphology: a European perspective. In: Shroder J, Butler DR, Hupp CR (eds) Treatise on Geomorphology, vol 12., ecogeomorphologyAcademic Press, San Diego, pp 37-52

Romanenko VD (2004) Bases of hydrology of land. Geneza, Kyiv

Romanowski J, Matuszkiewiecz J, Franz KW, Kowalska A, Kozłowska A et al (2005) Evaluation of ecological consequences of development scenarios for the Vistula River. Vistula Econet Development and Implementation VEDI. Institute of Biology CBE/PAN-IGiPZ/DLG/ALTERRA, Warsaw

Rulf J (1994) Pravěké osídlení střední Evropy a niva. In: Beneš J, Brůna V (eds) Archeologie a krajinná ekologie. Nadace Projekt Sever, Most, pp 55-64

Rusev IT (2003) Delta of the Dniester. History of nature management, ecological basis of monitoring, conservation and management of wetlands. Astroprint, Odessa

Rusev IT, Ruseva TD (2000) Renaturalisation of destructed areas of the Dniester delta as a measure of biodiversity rehabilitation of wetlands. Ecology-economic problems of Dniester. In: Abstrxct of international scientifiv-practical conference, Odessa, pp 66-68

Ruzickova H, Banasova V, Kalivoda H (2004) Morava River alluvial meadows on the Slovak Austrian border (Slovak part): plant community dynamics, floristic and butterfly diversity threats and management. J Nat Conserv 12:157-169

Rybanič R, Šeffer J, Čierna M (1999) Ekonomické hodnotenie prínosov ochrany a obnovy aluviálnych lúk. (Economic valuation of benefits from conservation and restoration of floodplain meadows). In: Šeffer J, Stanová J (eds) Morava river floodplain meadows-importance, restoration and management. DAPHNE_Centre for Applied Ecology, Bratislava, pp 147-160

Sallainé Kapocsi J, Danyik T (2015) Occurrence and control of common milkweed and false indigo within the territory of the Körös-Maros National Park. In: Csiszár Á, Korda M (eds) Practical experiences in invasive Alien plant control. Rosalia Handbooks. Duna-Ipoly National Park Directorate, Budapest, pp 109-119. http://www.dunaipoly.hu/hu/kiadvanyaink/25-rosalia-handbooks-3-practical-experiencesin-invasive-alien-plant-control/file. Accessed 12 Nov 2015

Schindler S, Kropik M, Euller K, Bunting SW, Schulz-Zunkel C et al (2013a) Floodplain management in temperate regions: is multifunctionality enhancing biodiversity? Environ Evid 2:10

Schindler S, Livoreil B, Sousa Pinto I, Araújo R, Zulka K-P et al (2013b) Final knowledge assessment reports of the 3 case studies and lessons learned. Deliverable 3.1 of the EU-FP7-project KNEU, contract No. 265299 http://biodiversityknowledge.eu/documents7792.html ?layout=edit\&id=88. Accessed 4 Apr 2016

Schindler S, Sebesvari Z, Damm C, Euller K, Mauerhofer V et al (2014) Multifunctionality of floodplain landscapes: relating management options to ecosystem services. Landscape Ecol 29:229-244

Schindler S, Livoreil B, Sousa Pinto I, Araújo RM, Zulka KP et al (2016) The network biodiversity knowledge in practice: insights from three trial assessments. Biodivers Conserv. doi:10.1007/s10531016-1128-4

Schmutz S, Kremser H, Melcher A, Jungwirth M, Muhar S, Waidbacher H, Zauner G (2014) Ecological effects of rehabilitation measures at the Austrian Danube: a meta-analysis of fish assemblages. Hydrobiologia 729(1):49-60

Scholz M, Mehl D, Schulz-Zunkel C et al (2012) Ökosystemfunktionen von Flussauen. Analyse und Bewertung von Hochwasserretention, Nährstoffrückhalt, Kohlenstoffvorrat, Treibhausgasemissionen und Habitatfunktion. Naturschutz Biol Vielfalt 124:2

Secchi S, Garvey J, Whiles M (2012) Multifunctional floodplain management: looking ahead from the 2011 Mississippi floods. Natl Wetl Newslett 34(5):21-25

Šeffer J, Stanová V (1998) The Morava River Floodplains. DAPHNE-Centre for Applied Ecology, Bratislava

Šeffer J, Stanová V (eds) (1999) Morava river floodplain meadows-importance, restoration and management. DAPHNE-Centre for Applied Ecology, Bratislava

Šeffer J, Stanová V, Mertanová S (1999) Obnova druhovo bohatých aluviálnych lúk-experimentálny prístup (Restoration of species-rich floodplain meadows-experimental approach). In: Seffer J, Stanová J (eds) Morava river floodplain meadows-importance, restoration and management. DAPHNE-Centre for Applied Ecology, Bratislava, pp 119-128

Sendzimir J, Magnuszewski P, Zs Flachner, Balogh P, Molnár G, Sárvári A, Zs Nagy (2007) Assessing the resilience of a river management regime: informal learning in a shadow network in the Tisza River Basin. Ecol Soc 13(1):11 
Silva JP, Toland J, Jones W, Eldridge J, Hudson T, Thorpe E, O'Hara E (2009) Protecting Europe's nature: learning from LIFE. Nature conservation best practices. Office for Official Publications of the European Communities, Luxembourg

Somlyódi L (ed) (2011) Magyarország vízgazdálkodása: helyzetkép és stratégiai feladatok (Water management of Hungary: report and strategy). Hungarian Academy of Sciences, Budapest

Somogyi S (2001) Természeti és társadalmi hatások a Duna mai vízrendszerében (Natural and societal drivers in the Danube basin). Földrajzi Értesítő 50:299-309

Stanová V, Valachovič M (eds) (2002) Katalóg biotopov Slovenska. DAPHNE-Centre for Applied Ecology, Bratislava

Stefanyshin DV (2010) On the prospects of hydropower in Ukraine and alternative choice in the development of the Dnieper cascade taking into account the risk. Hydropower Ukraine 3:5-11

Strohmaier B, Egger G, Janak M (2008) Feasibility study for a transnational Alpine Carpathian-Corridor Project. WWF Österreich, Vienna

Sundermann A, Antons C, Cron N, Lorenz A, Hering D, Haase P (2011) Hydromorphological restoration of running waters: effects on benthic invertebrate assemblages. Freshwater Biol 56:1689-1702

Szigetvári CS (2002) Initial steps in the regeneration of a floodplain meadow after a decade of dominance of an invasive transformer shrub, Amorpha fruticosa L. Tiscia 33:67-77

Szmańda JB, Lehotský M, Novotný J (2008) Sedimental record of flood events from years 2002 and 2007 in the Danube river overbank deposits in Bratislava. Morav Geograph Reports 16:2-8

Tkachenko VS (1975) Modern state of vegetation of small rivers basins of the Donets basin and its erosionpreventive and water protection role. Ukrain Bot J 32:65-70

Tockner K, Lorang MS, Stanford JA (2010) River flood plains are model ecosystems to test general hydrogeomorphic and ecological concepts. River Res Appl 26:76-86

UBA (Umweltbundesamt) (2014) Strategien zur Optimierung von Fließgewässer-Renaturierungsmaßnahmen und ihrer Erfolgskontrolle. UBA-Texte 43/2014, 4 Dessau-Roßlau

Uherčíková E, Pišút P, Hajdúk J (1999) Permanent monitoring plots and vegetation succession on the Gabčíkovo structure dikes. In: Mucha I (ed) Gabčíkovo Part of the Hydroelectric Power Project Environmental Impact Rewiew. Comenius University, Bratislava, pp 281-322

Van Beusekom EJ (2007) Bewogen aarde. Aardkundig erfgoed in Nederland. Matrijs, Utrecht

Van der Sluis T, Bloemmen M, Bouwma IM (2004) European corridors: strategies for corridor development for target species. Alterra, ECNC, Tilburg/Wageningen. http://content.alterra.wur.nl/webdocs/internet/ corporate/prodpubl/boekjesbrochures/ecnc_compleet.pdf. Accessed 12 Nov 2015

Van der Sluis T, Jongman R, Bouwma I, Wascher D (2012) Ein europäischer Biotopverbund-Herausforderungen an den europäischen Kooperations- und Gestaltungswillen. Nat Landsch 87(9):415

Vendrov SL (1970) Problems of transformation of river systems. Hydrometeoizdat publishing, Leningrad

Vyshnevsky BI, Stashuk VA, Sakevich AM (2011) Water utilization system in the Dnieper river basin. Interpress Ltd, Kyiv

Ward JV, Tockner K, Schiemer F (1999) Biodiversity of floodplain river ecosystems: ecotones and connectivity. Regul Rivers 15:125-139

Warren MS, Hill JK, Thomas JA et al (2001) Rapid responses of British butterflies to opposing forces of climate and habitat change. Nature 414:65-69

Weber T, Sloan A, Wolf J (2006) Maryland's Green Infrastructure Assessment: development of a comprehensive approach to land conservation. Landsc Urban Plan 77:94-110

Werners SE, Flachner Z, Matczak P, Falaleeva M, Leemans R (2009) Exploring earth system governance: a case study of floodplain management along the Tisza river in Hungary. Glob Environ Change 19:503-511

Wesselink A, Warner J, Abu Syed M, Chan F, Duc Tran D et al (2015) Trends in flood risk management in deltas around the world: are we going 'soft'? Int J Water Governance 3:25-46

Yatsyk AV, Gryshchenko YM, Volkova LA, Pasheniuk IA (2007) Water resources: use, protection, reconstruction, management. Geneza, Kyiv

Zagubizhenko NI (1999) Benthic fauna of lakes of the Dniprovsko-Orilsky reserve. Visnyk Dnipropetrovsk Univ Biol Ecol 6:130-134

Zagubizhenko NI, Khrystov OA, Kochet VN et al (2002) Hydroecological characteristics of the Bokovenki River. Problems of ecology and ecological education. In: Proceedings of the 1st international conference on IBI, Kryvyi Rig, pp 159-163

Zmelik K, Schindler S, Wrbka T (2011) The European Green Belt: international collaboration in biodiversity research and nature conservation along the former Iron Curtain. Innov Eur J Soc Sci Res 24:273-294 